KAROLYN SASSI OGLIARI

\title{
Efeitos intra-uterinos e pós-natais da exposição crônica ao combustível diesel sobre o aparelho reprodutor feminino
}

Tese apresentada à Faculdade de Medicina da Universidade de São Paulo para obtenção de título de Doutor em Ciências

Programa de Patologia

Orientador: Prof. Dr. Paulo Hilário Nascimento Saldiva

São Paulo 
Dados Internacionais de Catalogação na Publicação (CIP)

Preparada pela Biblioteca da

Faculdade de Medicina da Universidade de São Paulo

Creprodução autorizada pelo autor

Ogliari, Karolyn Sassi

Efeitos intra-uterinos e pós-natais da exposição crônica ao combustível diesel sobre o aparelho reprodutor feminino / Karolyn Sassi Ogliari. -- São Paulo, 2011.

Tese(doutorado)--Faculdade de Medicina da Universidade de São Paulo. Programa de Patologia.

Orientador: Paulo Hilário Nascimento Saldiva.

Descritores: 1.Reprodução 2.Folículo ovariano 3.Menopausa 4.Epigenômica 5.Emissões de veículos 6.Poluição 7.Endométrio 8.Camundongos

USP/FM/DBD-232/11 
Dedico esta Tese

Primeiramente, aos meus filhos Alícia e Luca Razão da minha existência;

Ao meu esposo Marcio, o qual sem o amor, a compreensão, a parceria e o estímulo, jamais eu poderia concluir este trabalho;

E aos meus pais Linor e Clarisa, meus exemplos de persistência e coragem para enfrentar qualquer adversidade da vida. 


\section{AGRADECIMENTOS}

A minha família Marcio Juliano Ogliari, Alícia Sassi Ogliari e Luca Sassi Ogliari, pela paciência e compreensão nos momentos em que me fiz ausente para a dedicação a este trabalho.

Ao meu orientador, Prof. Dr. Paulo Hilário Nascimento Saldiva, por ter me aceito como aluna e me proporcionado estímulo sempre frente às adversidades, simplificando o que parecia tão complicado.

A Prof ${ }^{a}$. Dr ${ }^{a}$. Marisa Dolhnikoff por todo o apoio e disponibilidade frente às dúvidas para que a publicação desta tese fosse da mais alta qualidade.

A Dra . Ana Júlia de Faria Coimbra Lichtenfels por ter auxiliado na execução dos experimentos com a câmara de exposição e estatística desta tese. Seu empenho foi fundamental para a credibilidade do trabalho. Minha profunda gratidão.

A Prof ${ }^{a}$. Dra . Mary Marchi, pela execução das amostragens das emissões do diesel, fundamentais para a interpretação dos resultados deste trabalho.

A $\mathrm{Dr}^{\mathrm{a}}$. Mariana Veras pelo auxílio nos experimentos de ciclicidade estral que contribuíram para os resultados deste estudo. 
A Dra ${ }^{a}$. José Mára de Brito. Sua ajuda foi indispensável na escrita desta tese.

Ao grupo de colaboradores do Laboratório de Anatomia Patológica do Instituto Central do Hospital da Clinicas de São Paulo pela confecção das lâminas para o estudo histológico.

As técnicas do laboratório de imunohistoquímica pela confecção das lâminas para análise de apoptose.

As secretárias do Prof. Dr. Paulo Saldiva, Fátima e Rosana, pelo grande apoio e eficiência na ponte entre orientador e aluno.

A todos que contribuíram direta ou indiretamente para que esta pesquisa se concretizasse. 


\section{NORMALIZAÇÃO ADOTADA}

Esta tese está de acordo com as seguintes normas, em vigor no momento desta publicação:

Referências: adaptado de International Committee of Medical Journals Editors (Vancouver).

Universidade de São Paulo, Faculdade de Medicina, Divisão de Biblioteca e Documentação, Guia de apresentação de dissertações, teses e monografias. Elaborado por Anneliese Carneiro da Cunha, Maria Júlia de A. L. Freddi, Maria F. Creatana, Marinalva de Souza Aragão, Suely Campos Cardoso, Valéria Vilhena. $3^{a}$ Ed. São Paulo: Divisão de Biblioteca e Documentação; 2011.

Abreviaturas dos títulos dos periódicos de acordo com List of Journals Indexed in Index Medicus. 


\section{SUMÁRIO}

Lista de abreviaturas e siglas

Lista de símbolos

Lista de figuras

Lista de tabelas

Lista de quadros

Resumo

Abstract

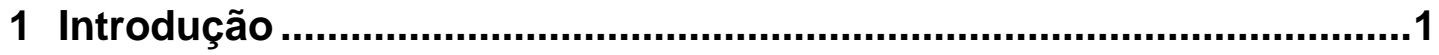

1.1 A poluição e seus componentes ........................................

1.2 Os órgãos reguladores da poluição.........................................

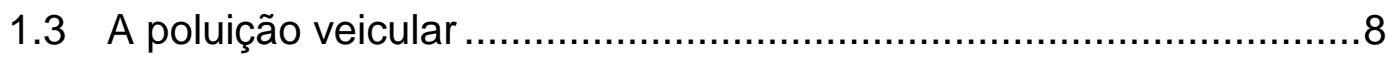

1.4 O óleo diesel ............................................................... 10

1.5 Efeitos do diesel sobre a saúde em geral e no sistema

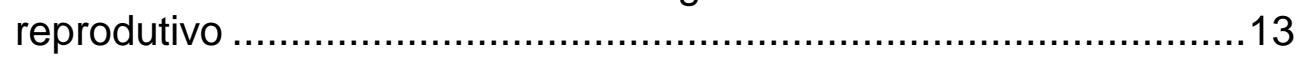

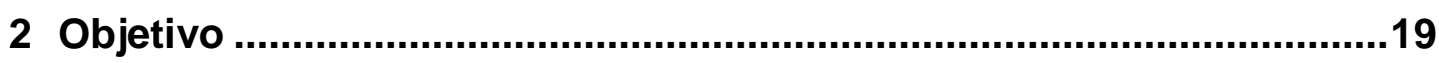

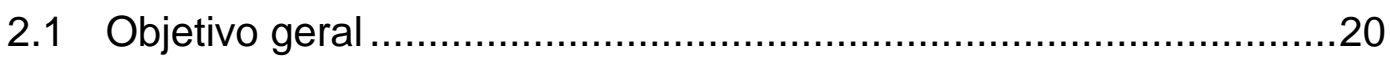

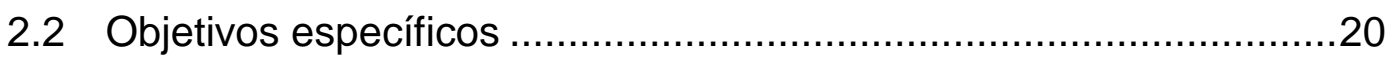

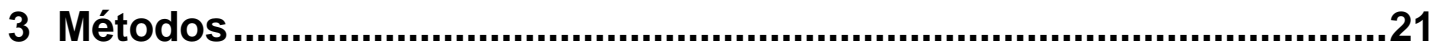

3.1 Condições gerais do experimento ....................................22

3.1.1 Especificações do combustível utilizado...........................22

3.1.2 O gerador de partículas de diesel..................................23

3.1.3 Caracterizações da exposição......................................28

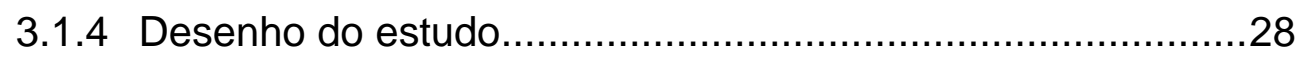

3.2 Análises dos componentes do diesel ......................................31

3.2.1 Análise do material particulado fino $\left(\mathrm{MP}_{2.5}\right)$ da exaustão do diesel: gravimetria, reflectância e espectrometria de fluorescência de raio-x (FRX)

3.2.2 Análise de hidrocarbonetos policíclicos aromáticos no

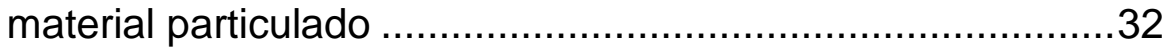

3.2.3 Analise da fração orgânica volátil e composição gasosa.......33

3.3 Análise da toxicidade nos órgãos reprodutivos ............................35

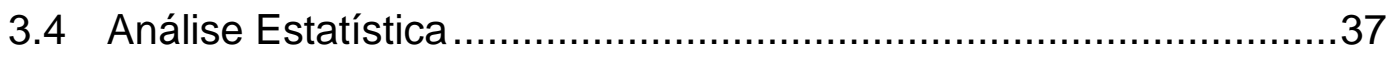




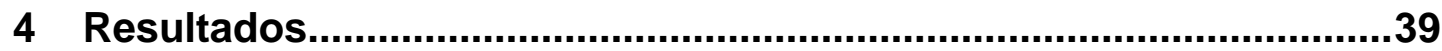

4.1 Análises dos parâmetros de exposição em tempo real ....................40

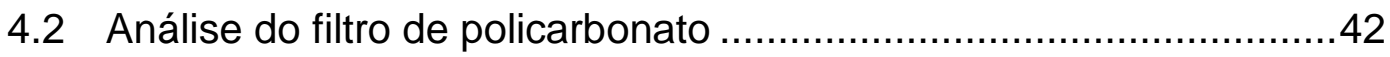

4.2.1 Quantificação do material particulado fino $\left(\mathrm{MP}_{2.5}\right)$ por

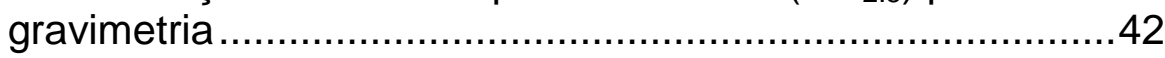

4.2.2 Quantificação do carbono negro por reflectância de luz........43

4.2.3 Caracterização dos elementos inorgânicos do por espectrometria de fluorescência de Raio-X ...........................44

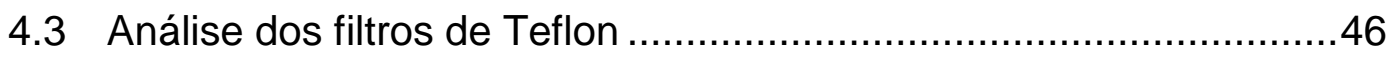

4.3.1 Caracterização dos hidrocarbonetos policíclicos

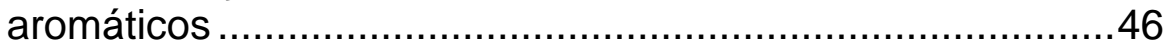

4.4 Análise da fração gasosa da exaustão do diesel ...........................47

4.4.1 Identificação e quantificação de compostos orgânicos voláteis

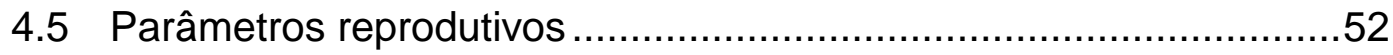

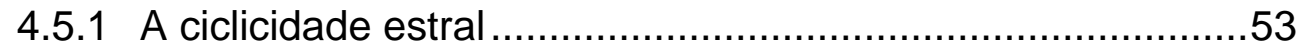

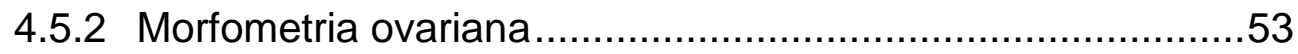

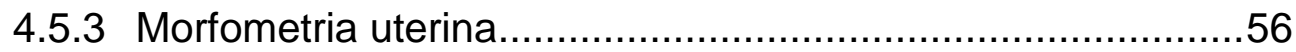

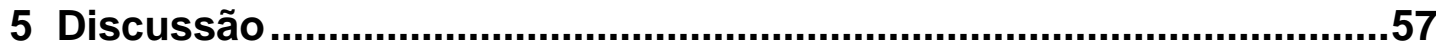

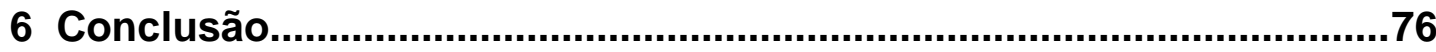

7 Referências...........................................................................................

Apêndice 


\section{LISTA DE ABREVIATURAS E SIGLAS}

$\begin{array}{ll}\text { FMUSP } & \text { Faculdade de Medicina da Universidade de São Paulo } \\ \text { LPAE } & \text { Laboratório de Poluição Atmosférica Experimental } \\ \text { LQA } & \text { Laboratório de Química Atmosférica } \\ \text { ABNT } & \text { Associação Brasileira de Normas Técnicas } \\ \text { NBR } & \text { Normas Brasileiras } \\ \text { IBGE } & \text { Instituto Brasileiro de Geografia e Estatística } \\ \text { ANP } & \text { Agência Nacional do Petróleo, Gás Natural } \quad \text { Giocombustíveis } \\ & \text { Diário Oficial da União } \\ \text { WHO } & \text { Organização Mundial de Saúde } \\ \text { D.O.U. } & \text { World Health Organization } \\ & \end{array}$

PROCONVE Programa de Controle da Poluição do Ar por Veículos Automotores

EPA Agência de Proteção Ambiental

CONAMA Comissão Nacional do Meio Ambiente

IBAMA Instituto Brasileiro do Meio Ambiente e dos Recursos Naturais Renováveis 


\begin{tabular}{|c|c|}
\hline CEMIB & Centro Multidisciplinar para Investigação Biológica \\
\hline SPSS & Statistical Package for the Social Sciences \\
\hline MP & Material particulado \\
\hline $\mathrm{MP}_{10}$ & Material Particulado com diâmetro inferior a $10 \mu \mathrm{m}$ \\
\hline $\mathrm{MP}_{2.5}$ & Material Particulado com diâmetro inferior a 2,5 $\mu \mathrm{m}$ \\
\hline $\mathrm{MP}_{0,1}$ & Material Particulado com diâmetro inferior a 2,5 $\mu \mathrm{m}$ \\
\hline CN & Carbono negro \\
\hline PTS & Partículas totais em suspensão \\
\hline $\mathrm{CC}$ & Grupo exposto a ar filtrado no período intra-útero e pós-natal \\
\hline EC & $\begin{array}{l}\text { Grupo exposto a combustão do diesel no período intra-útero } \\
\text { e a ar filtrado no período pós-natal }\end{array}$ \\
\hline CE & $\begin{array}{l}\text { Grupo exposto a ar filtrado no período intra-útero e a } \\
\text { combustão do diesel no período pós-natal }\end{array}$ \\
\hline EE & $\begin{array}{l}\text { Grupo exposto à combustão do diesel nos períodos intra- } \\
\text { útero e pós-natal }\end{array}$ \\
\hline B100 & 100\% Biodiesel \\
\hline B50 & $50 \%$ Biodiesel acrescido de 50\% de óleo diesel \\
\hline B3 & 3\% Biodiesel acrescido de $97 \%$ de óleo diesel \\
\hline Máx & Máximo \\
\hline
\end{tabular}




\begin{tabular}{|c|c|}
\hline Min & Mínimo \\
\hline DP & Desvio padrão \\
\hline HPAs & Hidrocarbonetos policíclicos aromáticos \\
\hline HPLC & High-performance liquid chromatography \\
\hline COVs & Compostos Orgânicos Voláteis \\
\hline $\mathrm{HE}$ & Hematoxilina e eosina \\
\hline FRX & Fluorescência de raio-X \\
\hline $\mathrm{HC}$ & Hidrocarbonetos \\
\hline HEX & n-hexano \\
\hline ACT & Acetona \\
\hline $\mathrm{ACN}$ & Acetonitrila \\
\hline FEN & Fenantreno \\
\hline ANT & Antraceno \\
\hline FLR & Fluoranteno \\
\hline PYR & Pireno \\
\hline $\mathrm{BaA}$ & Bezo[a]antraceno \\
\hline CRY & Criseno \\
\hline BkF & zo[k]fluoranteno \\
\hline
\end{tabular}




\begin{tabular}{|c|c|}
\hline $\mathrm{BaP}$ & Benzo[a]pireno \\
\hline $\mathrm{BeP}$ & Benzo[e]pireno \\
\hline DahA & Dibenzo[a,h]antraceno \\
\hline BeAcf & Benzo[e]acefenantrileno \\
\hline IND & Indeno[1,2,3-cd]pireno \\
\hline BghiP & Benzo[g,h,i]perileno \\
\hline $\mathrm{Ar}$ & Argônio \\
\hline $\mathrm{Mg}$ & Magnésio \\
\hline $\mathrm{Al}$ & Alumínio \\
\hline $\mathrm{Si}$ & Silício \\
\hline $\mathrm{P}$ & Fósforo \\
\hline $\mathrm{S}$ & Enxofre \\
\hline $\mathrm{Cl}$ & Cloro \\
\hline $\mathrm{K}$ & Potássio \\
\hline $\mathrm{Ca}$ & Cálcio \\
\hline $\mathrm{Ti}$ & Titânio \\
\hline V & Vanádio \\
\hline $\mathrm{Cr}$ & Cromo \\
\hline
\end{tabular}




\begin{tabular}{|c|c|}
\hline $\mathrm{Mn}$ & Magnésio \\
\hline $\mathrm{Fe}$ & Ferro \\
\hline $\mathrm{Ni}$ & Níquel \\
\hline $\mathrm{Cu}$ & Cobre \\
\hline $\mathrm{Zn}$ & Zinco \\
\hline $\mathrm{Se}$ & Selênio \\
\hline $\mathrm{Br}$ & Bromo \\
\hline $\mathrm{Pb}$ & Chumbo \\
\hline $\mathrm{O}_{2}$ & Oxigênio \\
\hline $\mathrm{H}_{2}$ & Hidrogênio \\
\hline $\mathrm{H}_{2} \mathrm{O}$ & Água \\
\hline $\mathrm{CO}$ & Monóxido de carbono \\
\hline $\mathrm{CO}_{2}$ & Dióxido de carbono \\
\hline $\mathrm{N}_{2}$ & Nitrogênio \\
\hline NO & Óxido nítrico \\
\hline $\mathrm{NO}_{2}$ & Dióxido de nitrogênio \\
\hline $\mathrm{N}_{2} \mathrm{O}$ & Óxido nitroso \\
\hline $\mathrm{NO}_{\mathrm{x}}$ & Óxidos de nitrogênio \\
\hline
\end{tabular}




$\begin{array}{ll}\mathrm{SO}_{x} & \text { Óxidos de enxofre } \\ \mathrm{SO}_{2} & \text { Ozóxido de enxofre } \\ \mathrm{O}_{3} & \text { Hélio } \\ \mathrm{He} & \text { Metano } \\ \mathrm{CH} & \\ \mathrm{R}-\mathrm{CHO} & \text { aldeídos } \\ \mathrm{DES} & \text { dietilestilbestrol } \\ \mathrm{PNMC} & \text { 4-nitro-m-cresol } \\ \mathrm{PNMPP} & \text { 4-nitro-3-fenilfenol }\end{array}$




\section{LISTA DE SÍMBOLOS}

\begin{tabular}{|c|c|}
\hline$\%$ & percentual \\
\hline$>$ & maior \\
\hline$<$ & menor \\
\hline$=$ & igual \\
\hline${ }^{\circ} \mathrm{C}$ & graus Celsius \\
\hline $\mathrm{mL}$ & mililitro \\
\hline$\mu \mathrm{L}$ & microlitro \\
\hline$\mu \mathrm{m}$ & micrômetro \\
\hline$\mu \mathrm{g} / \mathrm{m}^{3}$ & micrograma por metro cúbico \\
\hline $\mathrm{mg} / \mathrm{m}^{3}$ & miligrama por metro cúbico \\
\hline $\mathrm{mg} / \mathrm{kg}$ & miligrama por kilograma \\
\hline $\mathrm{L} / \mathrm{min}$ & litro por minuto \\
\hline ppm & partes por milhão \\
\hline ppmv & partes por milhão por volume \\
\hline $\mathrm{km}^{2}$ & quilômetro quadrado \\
\hline $\mathrm{Km}$ & quilômetro \\
\hline
\end{tabular}


$\min$

minuto

$\mathrm{kg} / \mathrm{m}^{3} \quad$ kilograma por metro cúbico

$\mathrm{mm}^{2} / \mathrm{s} \quad$ milímetros quadrados por segundo

$\mathrm{ng} / \mathrm{m}^{3} \quad$ nanograma por metro cúbico 


\section{LISTA DE FIGURAS}

Figura 1. Planta baixa da área de instalação da câmara de intoxicação $\left(7,12 \mathrm{~m}^{2}\right)$

Figura 2. Gerador de partículas do material da exaustão dos combustíveis diesel-biodiesel

Figura 3. $A$ - caixa redutora de ruído; $B$ - gerador a diesel dentro da caixa e $C$ - câmara de intoxicação para roedores

Figura 4. Sistema de filtragem de ar

Figura 5. Ilustração esquemática dos grupos de estudo

Figura 6. Representação gráfica dos parâmetros medidos em tempo real no período intra-uterino.

Figura 7. Representação gráfica dos parâmetros medidos em tempo real no período pós-natal

Figura 8. Demonstração gráfica da proporção de carbono negro presente no material particulado dos grupos expostos ao diesel.

Figura 9. Demonstração de valores pontuais da concentração total dos COVs amostrados nos grupos controle e exposto a diesel.

Figura10. Composição dos COVs nos grupos expostos a ar filtrado e a diesel.

Figura 11. Representação gráfica da fração de área ocupada por folículos primordiais em todos os grupos. O círculo central representa a média e as barras verticais o erro padrão

Figura12. Representação gráfica da fração de área ocupada por folículos primários em todos os grupos. O círculo central representa a média e as barras verticais o erro padrão

Figura 13. Múltiplas alterações biológicas causadas por exposições a agentes químicos que desencadeiam mecanismos epigenéticos, como a metilação de DNA, modificação de histonas e formação de RNA não-codificante levando a alterações de expressão gênica e condensação de cromatina, influenciando os riscos para doenças. 


\section{LISTA DE TABELAS}

Tabela 1. Classificação dos estágios do ciclo estral através da análise celular dos lavados vaginais

Tabela 2. Estatística descritiva de CO, temperatura, umidade relativa e ruído nas câmaras de exposição de todos os grupos medidos em tempo real durante 1 hora de exposição

Tabela 3. Valores descritivos dos parâmetros mensurados nos filtros: material particulado e carbono negro. Os valores estão apresentados como média e desvio padrão

Tabela 4. Valores descritivos dos compostos inorgânicos presentes durante a exposição. Os valores estão apresentados como média e desvio padrão.

Tabela 5. Valores descritivos dos HPAs. Os valores estão apresentados como mínimos e máximos.

Tabela 6. Valores de COVs mensurados através de amostras pontuais dos grupos expostos a ar filtrado e grupos expostos à exaustão do diesel

Tabela 7. Estatística descritiva dos compostos orgânicos voláteis (aromáticos, alcanos, alcenos, alkadienos) para todas as amostras. Os resultados estão expressos em valores mínimos, máximos e a soma dos compostos na amostra.

Tabela 8. Valores descritivos da ciclicidade analisada dos quatro grupos

Tabela 9. Estatística descritiva da fração de área (\%) ocupada por folículos, corpos lúteos e estroma ovariano para os quarto grupos de estudo (exposição intra-uterina e pós-natal)

Tabela 10. Valores descritivos da fração de área (\%) dos parâmetros uterinos analisados (epitélio superficial endometrial, glândulas endometriais e estroma endometrial) dos quatro grupos analisados 


\section{LISTA DE QUADROS}

Quadro 1. Padrões nacionais de qualidade do ar. Fonte: CONAMA, 1990 ...5

Quadro 2. Limites estabelecidos pela OMS para poluentes atmosféricos.

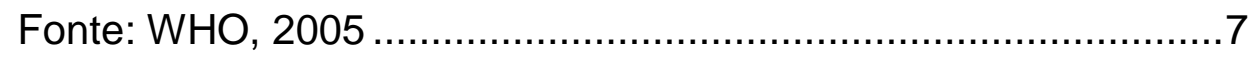

Quadro 3. Propriedades físicas do óleo diesel........................................23

Quadro 4. Diretrizes da Qualidade de Ar e Metas Provisórias para Material Particulado: média diária (24horas de exposição) .59

Quadro 5. Diretrizes da Qualidade de Ar e Metas Provisórias para Material Particulado: média anual..... 


\section{RESUMO}

Ogliari KS. Efeitos intra-uterinos e pós-natais da exposição crônica ao combustível diesel sobre o aparelho reprodutor feminino [tese]. São Paulo: Faculdade de Medicina, Universidade de São Paulo; 2011. 92p.

INTRODUÇÃO. Os efeitos da poluição atmosférica sobre a saúde humana são cada vez mais reconhecidos. A exposição ao combustível diesel, que contribui significativamente para a poluição em zonas de tráfego veicular intenso, pode ser ao menos parcialmente, responsável por estes efeitos. Estudos epidemiológicos demonstram maior incidência de pré-eclampsia, prematuridade e baixo peso ao nascer. Maiores taxas de falha de implantação e alterações da morfologia placentária são demonstrados em estudos experimentais. OBJETIVO. Análise morfológica do ovário e do útero de camundongos após exposição crônica ao combustível diesel durante a fase intra-uterina e pós-natal. MÉTODO. Estudo experimental prospectivo com crossover. Camundongos foram expostos durante uma hora a doses de combustão do diesel que correspondem a média diária de material particulado fino $\left(\mathrm{MP}_{2.5}\right)$ recomendado pela Organização Mundial da Saúde (WHO) e a doses acima da média anual recomendada pela mesma. A dose de exposição a $\mathrm{MP}_{2.5}$ foi abaixo da dose recomendada pela Comissão Nacional do Meio Ambiente (CONAMA). Quatro grupos foram formados: animais expostos a ar filtrado no período intra-uterino e no período pós-natal (CC); animais expostos a diesel apenas no período intra-uterino, sendo que no período pós-natal foram expostos a ar filtrado (EC); animais expostos a ar filtrado no período intra-uterino e a diesel no pós-natal (CE), e animais expostos a diesel nos períodos intra-uterino e pós-natal (EE). A análise morfométrica do ovário e do útero foi realizada para definir a área relativa ocupada por cada tipo de folículo, pelo corpo lúteo e pelo estroma, e a proporção de área ocupada por glândulas, estroma e epitélio no endométrio. RESULTADOS. Uma redução significativa de folículos primordiais foi observada em animais expostos a diesel durante o período intra-uterino $(p=0,035)$ e durante o período pós-natal $(p=0,015)$, assim como em animais expostos a diesel nos dois períodos ( $p=0.004)$. Houve redução significativa de folículos primários quando os animais foram expostos no período intrauterino $(p=0.04)$. Não foram demonstradas alterações significativas no útero. CONCLUSÃO. A exposição a níveis considerados aceitáveis de combustão do diesel é prejudicial ao potencial reprodutivo de camundongos fêmeas, diminuindo sua reserva ovariana ao atingir a maturidade sexual, sugerindo o envolvimento de alterações epigenéticas. Tal efeito aumenta o risco de menopausa precoce. Estes resultados sugerem que diretrizes ambientais sejam revisadas, já que a exposição prejudica gerações futuras, diminuindo a janela reprodutiva, já comprometida pelo desejo de grande parte das mulheres de adiar a maternidade.

Descritores: 1.Reprodução 2.Folículo ovariano 3.Menopausa 4.Epigenômica 5.Emissões de veículos 6.Poluição 7.Endométrio 8.Camundongos. 


\section{SUMMARY}

Ogliari KS. Intrauterine and postnatal effects of chronic diesel exhaust exposure on the female reproductive tract [thesis]. São Paulo: "Faculdade de Medicina, Universidade de São Paulo"; 2011. 92p.

BACKGROUND. There is growing awareness that ambient air pollution compromises human health. Exposure to diesel exhaust, which significantly contributes to pollution in heavy traffic areas, may be at least partially responsible for the observed effects of pollution on human health. Poor reproductive outcomes, such as preeclampsia, preterm deliveries and low birth weight, are described in epidemiological studies. Moreover, experimental evidence shows increased implantation failure rates and placental morphology alterations in exposed mice. OBJECTIVE. The purpose of this study was to analyse ovarian and uterine morphological changes resulting from chronic intrauterine and postnatal exposure to diesel exhaust in mice. METHODS. A experimental prospective crossover study. Mice were exposed to diesel exhaust with doses that correspond to the daily average $\mathrm{PM}_{2.5}$ levels reported by the World Health Organization (WHO) and above the annual average $\mathrm{PM}_{2.5}$ levels. The diesel exhaust exposure doses were also below daily and annual levels recommended by the National Council of Environment (CONAMA). Four groups were examined: intrauterine and postnatal clean, filtered air exposure; intrauterine exposure to diesel only; postnatal exposure to diesel only; and intrauterine and postnatal exposure to diesel. Morphometric analyses of the ovaries and uterus were performed to define the relative area occupied by follicles, corpus luteum and stroma. These analyses also aimed to determine the proportionate area of glands, the epithelial layer and stroma within the uterine endometrium. RESULTS: A significant reduction in primordial follicles was observed in intra-uterineexposed animals $(p=0.035)$, those exposed during the postnatal period $(p=0.015)$ and in animals exposed during both phases $(p=0.004)$. Primary follicles were reduced in animals exposed during pregnancy $(p=0.04)$. No significant changes were detected in uterine morphology. CONCLUSIONS: Intrauterine exposure to currently acceptable levels of diesel exhaust compromises the reproductive potential of female mice, diminishing ovarian reserve when sexual maturity is achieved suggesting involvement of epigenetic changes. This effect in turn increases the risk of premature menopause. These findings suggest that environmental guidelines should be reviewed because diesel exposure affects future generations. Premature menopause reduces the span of the reproductive window, which is already shortening due to women's desire to bear children later in life.

Descriptors: 1.Reproduction 2.Ovarian follicle 3.Menopause 4.Epigenomics 5.Vehicle emissions 6.Pollution 7.Endometrium 8.Mice 
1 Introdução 
A poluição atmosférica é uma das grandes preocupações mundiais devido ao aquecimento global, que afeta a saúde humana indiretamente (Ramanathan e Xu, 2010) e também pelos efeitos nocivos diretos provocados pelos poluentes levando ao aumento nas taxas de morbidade e mortalidade (WHO, 2005; Boldo, 2010; Maheswaran et al., 2010). Parte significativa dos poluentes atmosféricos é composta por emissões veiculares, especialmente em áreas urbanas. Diversos estudos têm demonstrado o impacto direto dos poluentes veiculares nos sistemas respiratório e cardiovascular causando, aproximadamente, dois milhões de mortes prematuras ao ano (WHO, 2005; Brunekreef et al., 2009; Jerrett et al., 2009; Hoffmann et al., 2007).

\subsection{A poluição e seus componentes}

A composição do ar ambiente puro é desconhecida, pois há milhares de anos o ser humano e fenômenos naturais como erupções de vulcões, decomposição de animais e plantas, emissões de aerossóis do oceano, têm influenciado esta composição. Sabe-se que os componentes primários do ar são o nitrogênio $\left(\mathrm{N}_{2}\right)$, oxigênio $\left(\mathrm{O}_{2}\right)$ e vapor de água $\left(\mathrm{H}_{2} \mathrm{O}\right)$. Cerca de $99 \%$ do ar são nitrogênio (78\%) e oxigênio (21\%). A fração restante é de substâncias como dióxido de carbono $\left(\mathrm{CO}_{2}\right)$, metano $\left(\mathrm{CH}_{4}\right)$, Hidrogênio $\left(\mathrm{H}_{2}\right)$, Argônio $(\mathrm{Ar})$ e Hélio (He) (EPA, 2010). 
Para que uma substância possa ser chamada de poluente, é necessário que determinada concentração desta possa ser capaz de interferir negativamente sobre a saúde humana, da fauna e da flora, bem como causar danos a materiais inanimados.

Há duas formas de apresentação de poluentes: material particulado (MP) e em forma de gases. O material particulado é toda partícula sólida ou líquida suspensa na atmosfera, e está presente, por exemplo, na poeira, fumaça e cinzas. Os gases são constituídos por substâncias como o monóxido de carbono (CO), óxido nítrico (NO) e componentes orgânicos voláteis (COV) (EPA, 2010).

Os poluentes ambientais podem ser classificados conforme sua fonte em biogênicos, de causas naturais, ou antropogênicos, causados pelo homem. A poluição de origem antropogênica é subdividida em fonte estacionária, proveniente de emissões de chaminés de fábricas, ou em fonte móvel, proveniente da combustão de combustíveis da frota veicular de determinado local (EPA, 2010).

O material particulado presente na atmosfera contém partículas primárias produzidas diretamente pelas fontes emissoras, bem como partículas secundárias, como sulfatos e nitratos, gerados pelo processo de conversão de gás a partículas a partir de SOx, NOx,e COVs (CETESB, 2008).

Segundo Pope (2000), a distribuição do MP pode ser classificada de trimodal, ou seja, frações grossas, finas e ultrafinas. A fração grossa ou $\mathrm{MP}_{10}$ são partículas com diâmetro aerodinâmico entre 2,5 e 10 um provenientes 
do solo, construções, estradas de rodagem; fração fina ou $\mathrm{MP}_{2.5}$ são partículas com diâmetro aerodinâmico menor que 2,5 $\mu \mathrm{m}$, provenientes da combustão incompleta de veículos automotores, indústrias e usinas termoelétricas; e a fração ultrafina, ou $\mathrm{MP}_{0,1}$, são partículas com diâmetro aerodinâmico menor que 0,1 $\mu \mathrm{m}$ provenientes da combustão incompleta de combustíveis fósseis. As partículas ultrafinas têm um tempo de residência na atmosfera relativamente curto, pois se agregam progressivamente para formar partículas maiores.

\subsection{Os órgãos reguladores da poluição}

O reconhecimento científico dos danos da poluição atmosférica sobre a saúde fez com que a Agência Norte-Americana de Proteção Ambiental (EPA), despertasse para a necessidade de criar um programa de controle de emissão de poluentes atmosféricos, e a partir da década de 60, estabeleceram padrões de qualidade do ar ambiente. Os padrões de qualidade do ar baseiam-se em diagnósticos ambientais. A partir destes padrões, consegue-se prever limites de concentração dentro de uma faixa considerada segura em relação aos efeitos adversos sobre a saúde.

Os poluentes controlados pela EPA são: $\mathrm{SO}_{2}, \mathrm{O}_{3}, \mathrm{NO}_{2}, \mathrm{CO}$, particulados totais em suspensão (PTS), e frações inaláveis como o $\mathrm{MP}_{10} \mathrm{e}$ o $\mathrm{MP}_{2,5}$, bem como o chumbo. 
No Brasil, o Conselho Nacional de Meio Ambiente - CONAMA (1990), através da criação da Resolução No 3 de 28/6/90, estabeleceu os padrões nacionais de qualidade do ar, com base na Portaria Normativa No 348 de 14/3/90 do Instituto Brasileiro do Meio Ambiente (IBAMA), incluindo a mesma padronização da EPA com exceção do chumbo e do $\mathrm{MP}_{2,5}$ (Quadro 1).

Quadro 1. Padrões nacionais de qualidade do ar. Fonte: CONAMA, 1990

\begin{tabular}{|c|c|c|c|}
\hline Poluente & Período de tempo & $\begin{array}{l}\text { Padrão primário } \\
\left(\mu \mathrm{m} / \mathrm{m}^{3}\right)\end{array}$ & $\begin{array}{c}\text { Padrão secundário } \\
\left(\mu \mathrm{m} / \mathrm{m}^{3}\right)\end{array}$ \\
\hline \multirow[t]{2}{*}{ PTS } & 24 horas & 240 & 150 \\
\hline & Média anual & 80 & 60 \\
\hline \multirow[t]{2}{*}{ MP } & 24 horas & 150 & 150 \\
\hline & Média anual & 50 & 50 \\
\hline \multirow[t]{2}{*}{ Fumaça } & 24 horas & 150 & 100 \\
\hline & Média anual & 60 & 40 \\
\hline \multirow[t]{2}{*}{$\mathrm{SO}_{2}$} & 24 horas & 365 & 100 \\
\hline & Média anual & 80 & 40 \\
\hline \multirow[t]{2}{*}{$\mathrm{NO}_{2}$} & 1 hora & 320 & 190 \\
\hline & Média anual & 100 & 100 \\
\hline \multirow[t]{2}{*}{$\mathrm{CO}$} & 1 hora & 35 ppm & 35 ppm \\
\hline & 8 horas & 9 ppm & 9 ppm \\
\hline $\mathrm{O}_{3}$ & 1 hora & 160 & 160 \\
\hline
\end{tabular}


No estado de São Paulo, a agência responsável pelo monitoramento do ar é a Companhia de Tecnologia de Saneamento Ambiental (CETESB). A partir de meados da década de 1980, criou-se uma rede automática de monitoramento do ar, com estações medidoras de poluição, distribuídas pela Região Metropolitana de São Paulo (RMSP) e Cubatão. Essa rede foi renovada em 1996 e contabiliza hoje um total de 29 estações.

Em 1986 no Brasil, foi aprovado pelo CONAMA o "Programa de Controle da Poluição do Ar por Veículos Automotores" (PROCONVE), destinado a reduzir os níveis de emissão de poluentes por veículos automotores, promover o desenvolvimento tecnológico para melhores motores, criar programas de inspeção e manutenção para veículos em uso, aprimorar as características técnicas dos combustíveis, promover a conscientização da população sobre a poluição do ar por veículos automotores e estabelecer medidas de avaliação dos resultados alcançados (CONAMA, 1986). Antes do PROCONVE, um veículo brasileiro emitia, em média, 54 g de CO por quilômetro percorrido. Hoje, a emissão reduziu em 98\%. O Brasil foi o primeiro país a retirar aditivos a base de chumbo da gasolina e a apresentar um programa de redução gradativa de enxofre existente no óleo diesel. O teor de enxofre no óleo diesel passou de 13000 ppm em 1980, para 500 ppm no diesel metropolitano e 2000 ppm no diesel interior em 2006 (La Rovere et al., 2007).

O que há de mais atual publicado sobre os padrões regulatórios dos poluentes ambientais é o guia de qualidade de ar da Organização Mundial 
da Saúde (OMS), revisado no ano de 2005, sendo que as edições prévias foram nos anos de 1987 e 1997 (Quadro 2) (WHO, 2005).

Quadro 2. Limites estabelecidos pela OMS para poluentes atmosféricos. Fonte: WHO, 2005

\begin{tabular}{|lll|}
\hline Poluente & Período de tempo & Concentração $\left(\boldsymbol{\mu g} / \mathbf{m}^{3}\right)$ \\
\hline $\mathrm{SO}_{2}$ & 24 horas & 20 \\
$\mathrm{NO}_{2}$ & 1 hora & 200 \\
& Média anual & 40 \\
$\mathrm{CO}$ & Média anual & 10000 \\
$\mathrm{O}_{3}$ & 8 horas & 100 \\
$\mathrm{MP}_{2.5}$ & 24 horas & 25 \\
& Média anual & 10 \\
$\mathrm{MP}_{10}$ & 24 horas & 50 \\
& Média anual & 20 \\
\hline
\end{tabular}

Dentro deste contexto, o monitoramento ambiental se constituiu em uma ferramenta de crucial importância para a avaliação da qualidade do ar, pois permitiu a adoção de medidas de controle de emissões, garantindo desta forma, a preservação dos níveis de concentrações ditos "seguros". 


\subsection{A poluição veicular}

Cerca de metade da poluição atmosférica é proveniente da frota veicular nos Estados Unidos (EPA, 2010). A frota automotiva da região metropolitana de São Paulo é responsável por 98\% das emissões de CO, $97 \%$ de hidrocarbonetos $(\mathrm{HC}), 96 \%$ de $\mathrm{NO}, 40 \%$ de $\mathrm{MP}$ e $33 \%$ de $\mathrm{SO}_{\mathrm{x}}$ (CETESB, 2008).

A frota veicular pode ser classificada de acordo com a sua função, em veículos que ocupam as estradas, como veículos leves destinados ao passeio ou transporte de passageiros, ou como veículos pesados, geralmente de carga. O combustível utilizado é o principal responsável pelas emissões poluidoras através da combustão e evaporação do mesmo. Os mais utilizados incluem a gasolina, o diesel, o biodiesel, álcool ou gás natural.

As emissões originadas pela frota veicular constituem (La Rovere et al., 2007):

$\checkmark$ Emissão de gases e partículas, subprodutos da combustão, pelo escapamento do veículo;

$\checkmark$ Evaporação do combustível (hidrocarbonetos);

$\checkmark$ Emissões de gases do cárter do motor;

$\checkmark$ Emissão de partículas provenientes do desgaste de freios, pneus e embreagem;

$\checkmark$ A poeira do solo levantada pelos automotores nas estradas;

$\checkmark$ Evaporação do combustível no momento do abastecimento do veículo. 
A gasolina e o óleo diesel são misturas de hidrocarbonetos (átomos de hidrogênio e carbono). Se a combustão ou queima dos combustíveis usados nos veículos fosse completa, todos os átomos de hidrogênio reagiriam com o ar formando água, e o carbono reagiria com o oxigênio do ar formando dióxido de carbono. O nitrogênio presente no ar permaneceria inalterado. No entanto, na prática, o que ocorre é uma combustão incompleta, que resulta na emissão de hidrocarbonetos, formação de óxidos de nitrogênio, monóxido de carbono, dióxido de carbono e água (EPA, 2010).

Alguns dos principais produtos da combustão em veículos automotores são o dióxido de carbono (CO2), água $\left(\mathrm{H}_{2} \mathrm{O}\right)$, monóxido de carbono (CO), hidrocarbonetos não ou parcialmente oxidados (HC), aldeídos (R-CHO), óxidos de nitrogênio (NOx), óxidos de enxofre (SOx) e material particulado (MP). O ozônio troposférico $\left(\mathrm{O}_{3}\right)$, outro importante poluente, tem a sua formação associada à presença de $\mathrm{HC}$ e $\mathrm{NO}_{x}$ (La Rovere et al., 2007).

Reduções significativas das emissões veiculares no Brasil vêm sendo possíveis devido às medidas adotadas pelo PROCONVE, como a política de utilização da injeção eletrônica de combustível e carburadores e conversores catalíticos nos veículos, além do estímulo a pesquisas tecnológicas aplicadas à melhorias constantes às empresas privadas para que estas enquadrem-se nos limites estabelecidos. 


\subsection{Oóleo diesel}

O óleo diesel é um combustível fóssil derivado da destilação do petróleo bruto usado em alguns veículos de passeio, porém mais em veículos pesados de carga (origem rodoviária) e em equipamentos utilizados em construções civis, locomotivas e navios (origem não-rodoviária) (EPA, 2002a).

Utilizado desde 1893, seu nome vem de Rudolph Diesel, engenheiro alemão que inventou um meio mecânico para explorar a reação química originada da mistura de óleo e do oxigênio presente no ar. Esta reação consiste em geração de energia através de uma explosão quando o combustível é comprimido. A energia gerada é usada para movimentar máquinas e motores de grande porte.

Assim como os demais combustíveis, as emissões do diesel são compostas por uma fração gasosa e outra de material particulado. Os componentes gasosos são o dióxido de carbono, oxigênio, nitrogênio, vapor de água, monóxido de carbono, compostos nitrogenados, compostos sulfúricos e hidrocarbonetos de baixo peso molecular. Dentre os hidrocarbonetos, os aldeídos, o benzeno, o 1,3-butadieno e os hidrocarbonetos policíclicos aromáticos são os mais tóxicos (Black et al., 1983). Os hidrocarbonetos podem estar presentes tanto na fração gasosa, quanto na fração particulada das emissões. O MP proveniente das emissões do diesel é composto por um carbono central com compostos orgânicos ligados a ele, bem como outros elementos como metais, sulfatos e nitratos (Abdul-Khalek et al., 1998). As 
partículas geradas são finas $\left(\mathrm{MP}_{2,5}\right)$ ou ultrafinas $\left(\mathrm{MP}_{0,1}\right)$ e portanto, são facilmente inaláveis (EPA, 2002a).

Dados dos Estados Unidos revelam que, excluindo as fontes naturais e outras fontes diversas de $\mathrm{MP}_{2.5}$, o MP proveniente da exaustão do diesel pode representar 23\% do inventário de partículas no ar em regiões urbanas, e a dose de exposição poderá chegar a 4,0 $\mu \mathrm{g} / \mathrm{m}^{3}$ a cada inalação do ar (CAL-EPA 1998a). A frota movida a diesel na região metropolitana de São Paulo é responsável por lançar no ar atmosférico cerca de 25\% de CO, 16\% de $\mathrm{HC}, 78 \%$ de $\mathrm{NO}_{x}, 28 \%$ de MP e $15 \%$ de $\mathrm{SO}_{x}$ (CETESB, 2008).

A exata proporção dos componentes químicos das emissões do diesel varia conforme sua origem, se proveniente de veículos ou de fontes estacionárias, e conforme sua mistura, como por exemplo, o percentual de enxofre e biodiesel contido nele.

A Agência Nacional do Petróleo, Gás Natural e Biocombustíveis (ANP, 2008) determinou que todo o óleo diesel rodoviário comercializado no país deveria conter mistura com biodiesel, em percentual conforme legislação vigente. Em 2009, a ANP estabeleceu como percentual mínimo obrigatório de $5 \%$ de adição de biodiesel ao óleo diesel comercializado ao consumidor, com fins de estimular o uso de fontes renováveis de combustíveis. O biodiesel é um combustível biodegradável derivado de fontes renováveis, que pode ser produzido a partir de gorduras animais ou de óleos vegetais, existindo dezenas de espécies vegetais no Brasil que podem ser utilizadas, tais como mamona, dendê (palma), girassol, babaçu, 
amendoim, pinhão manso e soja, dentre outras. Em sua forma pura, é simbolizada por B100 (ANP, 2008).

Além da vantagem de servirem como alternativas às fontes nãorenováveis de combustíveis fósseis, está implícito no uso do biodiesel a idéia de que este causaria menor dano à saúde e ao meio ambiente. Brito e colaboradores compararam a composição das emissões provenientes do diesel, do biodiesel e de misturas diesel/ biodiesel e seus efeitos sobre o sistema cardiovascular em modelo experimental. O estudo mostrou que a combustão do diesel aumentou as emissões de HPAs e COVs em relação à mistura diesel/ biodiesel a 50\% (B50) e ao biodiesel a 100\% (B100). Entretanto, a combustão do B50 aumentou as emissões de material particulado, carbono negro, metais e CO em relação ao diesel e B100. O diesel e o B100 aumentaram a variabilidade da freqüência cardíaca dos animais de seus respectivos grupos, e os grupos expostos a B50 e B100 apresentaram sinais de inflamação sistêmica. Todos os grupos mostraram sinais de inflamação pulmonar (Brito et al., 2010). Desta forma, o autor pôde demonstrar que o biodiesel pode também impactar negativamente sobre a saúde.

O carbono negro é um dos componentes do material particulado da emissão de combustíveis que sofrem combustão incompleta, como o diesel. Este consiste em um núcleo de carbono puro combinado a diversas outras moléculas orgânicas como sulfatos e nitratos. Atualmente, o carbono negro ou fuligem, está sendo considerado o segundo maior responsável pelo fenômeno de aquecimento global, ficando atrás apenas do dióxido de carbono (Ramanathan e Xu, 2010). Enquanto todos os combustíveis à base 
de carbono liberam $\mathrm{CO}_{2}$, apenas os que sofrem combustão incompleta produzem o carbono negro, que absorve luz e a transfere para a atmosfera, impedindo que a energia solar chegue ao solo (Bond e Sun, 2005). A fuligem pode ser considerada um marcador para emissões envolvendo o diesel.

\subsection{Efeitos do diesel sobre a saúde em geral e no sistema reprodutivo}

A EPA classifica os efeitos deletérios do diesel sobre a saúde humana conforme o tempo de exposição, em exposições agudas ou crônicas. As exposições agudas relacionam-se principalmente a efeitos transitórios no aparelho respiratório, que poderão ser repetidas ou não conforme o número de exposições, como reações alérgicas dos mais diversos níveis de gravidade. As exposições crônicas têm demonstrado efeitos deletérios a longo prazo, também principalmente no aparelho respiratório, como o câncer de pulmão. O sistema respiratório é considerado o órgão alvo das emissões do diesel devido ao percentual significativo de partículas finas e ultrafinas, o que as torna facilmente inaláveis, penetrando profundamente na árvore respiratória (EPA, 2002a).

Exposições agudas aos óxidos de enxofre e de nitrogênio, além dos aldeídos estão relacionadas à irritação ocular, nasal e faringe, além de sintomas neurofisiológicos como cefaléia, náuseas, vômitos e parestesias de extremidades (Calo et al., 2009). Altas concentrações de ozônio e o MP no 
ar ambiente estão relacionados a maior freqüência de crises de asma em atendimentos hospitalares (Di Giampaolo et al., 2011).

A relação da exposição crônica às emissões do diesel com alterações de provas de função pulmonar é controversa e mostra-se mais associado a algum componente específico como o óxido nitroso (Arbak et al., 2009; Ulvestad e Lund, 2003). Já a relação da exposição crônica às substâncias da combustão do diesel com o câncer de pulmão está comprovada através de metanálise de estudos envolvendo exposições a poluentes no ambiente de trabalho (Mahjub e Sadri, 2006).

Outros estudos mostram que a exposição crônica à poluição veicular está ligado a problemas cardiovasculares.

Jerret et al. (2009) associou a poluição veicular com os índices de mortalidade em Toronto no Canadá, mostrando um aumento de 17\% na mortalidade geral e $40 \%$ na mortalidade relacionada a causas circulatórias relacionado a níveis de $\mathrm{NO}_{2}, \mathrm{MP}_{2.5} \mathrm{e} \mathrm{O}_{3}$.

Maheswaran et al. (2010), em um estudo em Londres com pacientes que tiveram alta hospitar após apresentarem um primeiro episódio de acidente vascular cerebral, evidenciaram uma relação direta dos níveis de poluição com a mortalidade, sendo que aumentos de $10 \mu \mathrm{g} / \mathrm{m}^{3}$ no $\mathrm{NO}_{2}$ e no $\mathrm{MP}_{10}$ aumentavam o risco em $28 \%$ e $52 \%$ respectivamente. Dados epidemiológicos publicados por Hoffmann et al. (2007), envolvendo 4494 participantes na Alemanha, mostraram relação positiva com a poluição veicular e a doença coronariana. 
O impacto da poluição atmosférica nos desfechos reprodutivos vem sendo estudado já há algum tempo. A equipe de pesquisadores da Universidade de São Paulo publicou vários estudos ao redor do tema.

Estudos epidemiológicos como o de Pereira et al. (1998), mostrou uma associação positiva entre a mortalidade intra-uterina e a presença de $\mathrm{NO}_{2}$, $\mathrm{SO}_{2}$ e $\mathrm{CO}$ na cidade de São Paulo. Esta associação foi acompanhada de sinais de exposição fetal aos poluentes através de níveis de carboxihemoglobina detectados em amostras do sangue do cordão umbilical e os níveis ambientais de CO em crianças nascidas de mães não-fumantes. Gouveia et al., em 2004, estudou a relação da poluição atmosférica com o baixo peso ao nascer. A associação negativa foi encontrada entre o peso do recém-nascido e $\mathrm{MP}_{10}$ e o $\mathrm{CO}$ quando a exposição ocorreu no primeiro trimestre da gestação. Para cada 1ppm de $\mathrm{CO}$ acima da média, no primeiro trimestre, foi possível prever uma redução de $23 \mathrm{~g}$ no peso ao nascer. Complementando o período perinatal, Lin, et al., em 2004, mostrou relação entre as concentrações de $\mathrm{MP}_{10}$ e $\mathrm{SO}_{2}$ e mortes no período neonatal. Da mesma forma, um grupo de estudo da Califórnia, Estado Unidos, mostrou a relação de níveis de $\mathrm{MP}_{2.5}$ e $\mathrm{NO}_{x}$ com a ocorrência de prematuridade e préeclâmpsia. O risco para pré-eclâmpsia aumentou em 33\% durante os maiores níveis de $\mathrm{NO}_{x}$ e em $42 \%$ durante os maiores níveis de $\mathrm{MP}_{2.5}$ (Wu et al., 2009).

Um estudo experimental realizado em camundongos na cidade de São Paulo comparou a exposição à poluição atmosférica com camundongos que permaneceram expostos a ar filtrado e avaliaram o número de nascidos vivos, o numero de reabsorções (abortos precoces), mortes intra-uterinas, 
número de corpos lúteos e falhas de implantação. A concentração de $\mathrm{MP}_{10} \mathrm{e}$ $\mathrm{NO}_{2}$ foram $50 \%$ e $75 \%$ mais baixos no grupo exposto a ar filtrado. Os animais expostos à poluição mostraram ter número significativamente maior de falhas de implantação, ao passo que os animais expostos ao ar filtrado tiveram maior número de nascidos vivos (Mohallem et al., 2005).

Veras et al. (2008), ao analisarem placentas de camundongos expostos à poluição ambiental urbana na mesma cidade, puderam constatar que havia um aumento na superfície capilar fetal e uma redução do volume, da superfície e do calibre dos vasos na face materna placentária em animais expostos à poluição. Como foi constatado um menor peso ao nascer dos animais expostos, estes achados foram interpretados como uma reação compensatória do feto, embora sem êxito, para aumentar sua superfície de troca.

Além dos efeitos demonstrados nesses estudos, que apresentam conseqüências mais imediatas sobre diversos parâmetros reprodutivos, Lichtenfels et al., em 2007, evidenciou uma importante influência da poluição atmosférica no curso da evolução biológica das espécies, o que poderá gerar conseqüências a longo prazo. Ao analisar a razão sexual de nascidos vivos entre janeiro de 2001 a dezembro de 2003 na cidade de São Paulo e correlacionar aos níveis de $\mathrm{MP}_{10}$ registrados, foi possível verificar uma associação negativa entre os dois parâmetros no que tange ao nascimento de crianças do sexo masculino. Como análise complementar, um estudo em camundongos foi realizado com dois grupos, um exposto à poluição atmosférica e outro exposto a ar filtrado. Não houve diferença nos dois grupos em relação ao número total de nascidos vivos, entretanto, repetiu-se 
o resultado de menor número de nascidos vivos machos no grupo exposto à poluição, sugerindo uma influência na proporção X:Y dos espermatozóides. A análise histológica do testículo dos animais mostrou uma redução significativa no número de espermatozóides e no total de células germinativas no grupo exposto.

Levando-se em conta que a poluição veicular é a maior responsável pelos níveis de poluição atmosférica em São Paulo, pode-se concluir que os resultados apresentados são diretamente influenciados por esta.

Em conformidade com Lichtenfels et al. (2008), outros grupos de estudo têm demonstrado uma queda na concentração e número total de espermatozóides na população ao longo dos anos decorrente do aumento da poluição. Huang et al. (2010), publicaram dados sobre os parâmetros seminais de homens chineses nos últimos 24 anos. Não houve diferença significativa entre os anos de 1985 a 1994, porém os últimos 14 anos do estudo demonstraram uma redução de 1,4\% ao ano na concentração de espermatozóides e uma redução anual de 2,15\% na contagem total de espermatozóides. Estas mudanças foram atribuídas ao agravo da poluição ambiental causadas pelo grande desenvolvimento industrial da China nos últimos anos.

Estudos experimentais na esfera de reprodução masculina têm demonstrado possíveis mecanismos fisiopatológicos para as alterações encontradas na população (Povey e Stocks, 2010). Watanabe, em Tókio, realizou estudo em ratos dividindo-os em três grupos, um exposto às emissões do diesel, outro exposto apenas â fase gasosa das emissões e outro grupo exposto a ar filtrado. Os dois grupos expostos ao diesel apresentaram aumento 
dos níveis de testosterona e estrogênio, diminuição dos níveis dos hormônios FSH e LH e inibição da espermatogênese. Este estudo pôde demonstrar que os efeitos sobre a espermatogênese foram causados pela fração gasosa da queima do diesel (Watanabe e Oonuki, 1999).

Os efeitos da poluição na esfera reprodutiva também foram observados em experimentos in vitro. Maluf et al., em 2009, observaram que a exposição à poluição atmosférica de camundongos no período intra-uterino e pós-natal ocasionava uma alteração na distribuição das células do blastocisto, levando a um desvio de células para a formação do trofoblasto em detrimento da massa interna do embrião, sem a alteração no número total de células. Em outro estudo, foi observado o desenvolvimento inicial de embriões de camundongos quando introduzido no meio de cultura diferentes doses de MP. (Januário et al.,2010). Dentre os passos da fertilização assistida dos animais, foram observadas as mesmas alterações morfológicas no blastocisto nos grupos expostos, descritos por Maluf et al.(2009). Tais observações poderiam ser responsáveis pelas maiores taxas de falhas implantacionais observados por Mohallem et al., em 2005.

Até o momento, não há dados na literatura mostrando os efeitos da exposição crônica das emissões do diesel sobre o aparelho reprodutor feminino com enfoque na reserva ovariana e em alterações endometriais.

O objetivo deste estudo é tentar identificar possíveis alterações nesta esfera, causados por emissões de um combustível extremamente comum e com grande participação na poluição a que a população está exposta em grandes áreas urbanas, identificando também o período mais suscetível, se intra-uterino ou pós-natal. 
2 Objetivo

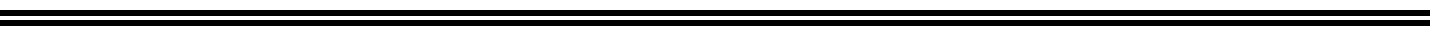




\subsection{Objetivo geral}

Analisar os efeitos da exposição crônica à combustão do diesel sobre o aparelho reprodutor feminino de camundongos ao atingir a maturidade sexual, quando a exposição ocorreu no período intra-uterino e pós-natal ou em ambos.

\subsection{Objetivos específicos}

$\checkmark$ Manter a dose de exposição à combustão do diesel dentro da média diária recomendada pela Organização Mundial da Saúde (OMS), porém acima de sua média anual ideal, e dentro dos limites da Comissão Nacional do Meio Ambiente (CONAMA).

$\checkmark$ Caracterizar a composição do material particulado e da fração gasosa do diesel a que os animais foram expostos.

$\checkmark$ Avaliar os efeitos do material de combustão do diesel sobre a ciclicidade estral.

$\checkmark$ Avaliar, através de morfometria, os efeitos da combustão do diesel sobre o ovário com quantificação de folículos primordiais, primários, secundários, corpos lúteos e estroma ovariano.

$\checkmark$ Avaliar, através de morfometria, os efeitos da combustão do diesel sobre o endométrio com quantificação de epitélio, glândulas e estroma endometrial. 


\section{Métodos}




\subsection{Condições gerais do experimento}

Este estudo foi realizado no Laboratório de Poluição Atmosférica Experimental (LPAE) do Departamento de Patologia da Faculdade de Medicina da Universidade de São Paulo, São Paulo, SP, Brasil, mediante aprovação da Comissão de Ética para Análise de Projetos de Pesquisa da Diretoria Clínica do Hospital das Clínicas e da Faculdade de Medicina da Universidade de São Paulo sob o número 0806/07 (APÊNDICE).

Os experimentos foram conduzidos seguindo as normas nacionais de ética na pesquisa com animais (Lei Federal número 6638 de 08/05/1979).

\subsubsection{Especificações do combustível utilizado}

O combustível utilizado foi diesel metropolitano (500 ppm de enxofre, acrescido de 3\% de biodiesel) comercializado na cidade de São Paulo pela Combuluz, distribuidora autorizada da Petrobrás, e o mesmo lote foi utilizado durante todo o experimento. O quadro 3 demonstra as propriedades físicas do óleo diesel utilizado. 
Quadro 3. Propriedades físicas do óleo diesel

\begin{tabular}{|c|c|c|c|c|}
\hline PARÂMETRO & UNIDADE & VALOR & ASPECTO & METODOLOGIA \\
\hline \multicolumn{5}{|l|}{ APARÊNCIA } \\
\hline $\begin{array}{l}\text { Aspecto } \\
\text { Cor }\end{array}$ & & & límpido & $\begin{array}{l}\text { Visual } \\
\text { Visual }\end{array}$ \\
\hline \multicolumn{5}{|l|}{ COMPOSIÇÂO } \\
\hline $\begin{array}{l}\text { Teor de biodiesel } \\
\text { Enxofre total, máx. }\end{array}$ & $\begin{array}{l}\% \mathrm{vol} \\
\mathrm{mg} / \mathrm{kg}\end{array}$ & $\begin{array}{c}3 \\
500 \\
\end{array}$ & & $\begin{array}{l}\text { Espectrometria de } \\
\text { Infravermelho } \\
\text { ABNT - NBR14875 }\end{array}$ \\
\hline \multicolumn{5}{|l|}{ VOLATILIDADE } \\
\hline $\begin{array}{l}\text { DESTILAÇÃO } \\
\text { 10\% vol. Recuperado } \\
50 \% \text { vol. Recuperado } \\
85 \% \text { vol. Recuperado } \\
95 \% \text { vol. Recuperado } \\
\text { Massa específica } \\
\text { Ponto de fulgor, min }\end{array}$ & ${ }^{\circ} \mathrm{Cg} / \mathrm{m}^{3}$ & $\begin{array}{c}\text { anotar } \\
245 \text { a } 310 \\
360 \\
\text { anotar } \\
820 \text { a } 865 \\
38\end{array}$ & & $\begin{array}{l}\text { ABNT - NBR 7148, NBR } 14065 \\
\text { ABNT - NBR 7974, NBR } 14598\end{array}$ \\
\hline \multicolumn{5}{|l|}{ FLUIDEZ } \\
\hline $\begin{array}{l}\text { viscosidade a } 40^{\circ} \mathrm{C} \\
\text { ponto de entupimento de } \\
\text { filtro a frio, máx }\end{array}$ & $\begin{array}{c}\left(\mathrm{mm}^{2} / \mathrm{s}\right) \\
{ }^{\circ} \mathrm{C}\end{array}$ & $\begin{array}{l}2,0 \text { a } 5,0 \\
3 \text { a } 12\end{array}$ & & $\begin{array}{l}\text { ABNT - NBR } 10441 \\
\text { ABNT- NBR } 14747\end{array}$ \\
\hline \multicolumn{5}{|l|}{ COMBUSTÃO } \\
\hline $\begin{array}{l}\text { numero de cetano, min. } \\
\text { cinzas, máx. }\end{array}$ & $\%$ massa & $\begin{array}{c}42 \\
0,25\end{array}$ & & ABNT - NBR 9842 \\
\hline \multicolumn{5}{|l|}{ CORROSÃO } \\
\hline $\begin{array}{l}\text { corrosividade ao cobre, } \\
3 \text { h a } 50^{\circ} \mathrm{C} \text {, máx. }\end{array}$ & & 1 & & ABNT - NBR 9842 \\
\hline \multicolumn{5}{|l|}{ CONTAMINANTES } \\
\hline água/sedimentos, máx. & $\%$ volume & 0,05 & & ABNT- NBR 14647 \\
\hline \multicolumn{5}{|l|}{ LUBRICIDADE } \\
\hline Lubricidade, máx. & Micron & 460 & & \\
\hline
\end{tabular}

Resolução ANP no 15 de 17.07.2006 - DOU 19.07.2006 - Estabelece as especificações do óleo diesel e mistura óleo diesel / biodiesel - B3 de uso rodoviário, para comercialização em todo o território nacional, e define obrigações dos agentes econômicos sobre o controle da qualidade do produto. Fonte: ANP, 006.

\subsubsection{O gerador de partículas de diesel}

A área total ocupada pelo gerador de partículas de poluentes provenientes da queima do combustível diesel e as câmaras de exposição foi de $7,12 \mathrm{~m}^{2}$ (Figura 1). Este sistema foi desenvolvido no LPAE - FMUSP 
com o objetivo de simular exposições em pequenos animais por via inalatória, com possibilidade de coleta de amostragens, em tempo real, de material particulado e gases provenientes desta combustão.

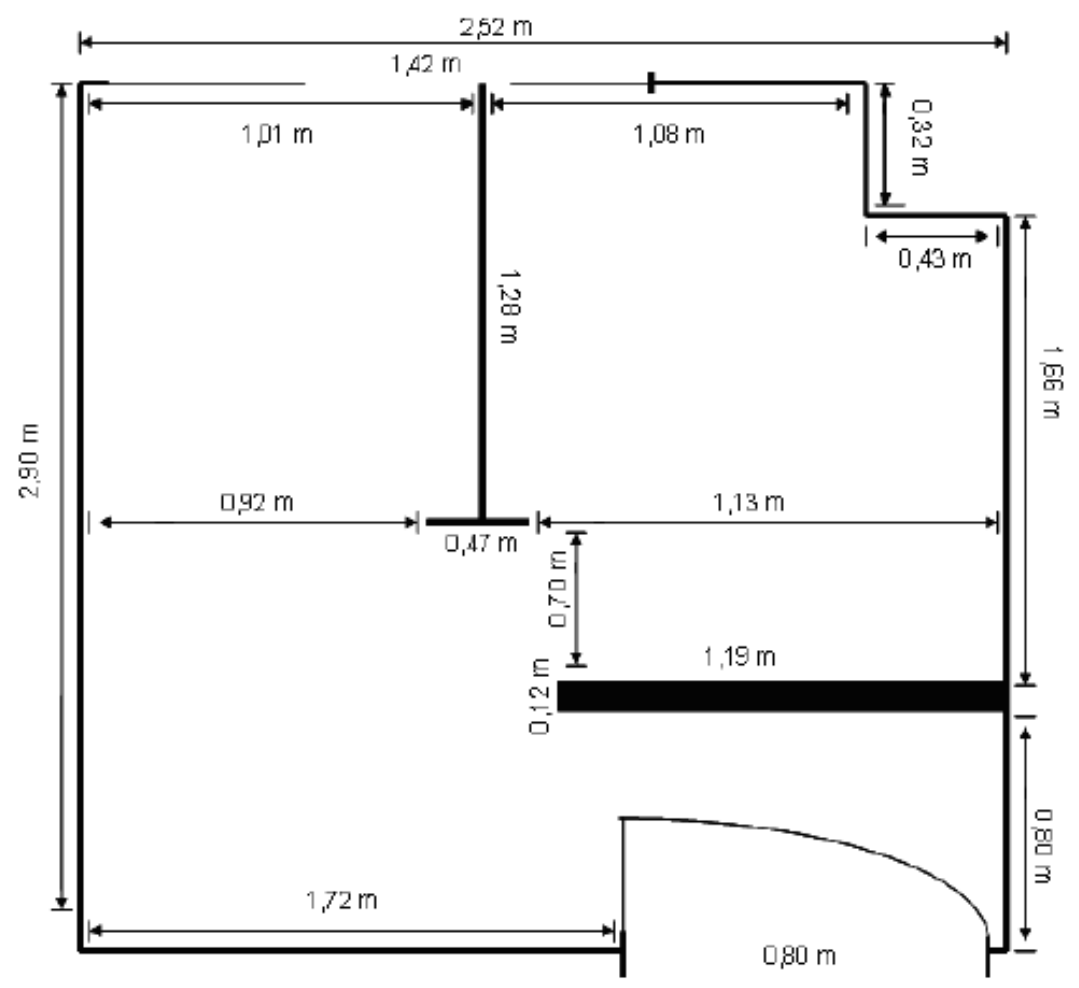

Figura 1. Planta baixa da área de instalação da câmara de intoxicação $\left(7,12 \mathrm{~m}^{2}\right)$

A figura 2 descreve o sistema de exposição. Este sistema é composto por um gerador portátil estacionário de energia a diesel (BD-2500 CFE, Branco, China), um sistema de filtragem do ar ambiente (mechanic and chemical filter of air, modelo ECU-100, Purafil, EUA), uma câmara de exposição e por sistemas de coleta e amostragem das partículas e gases emitidos durante a exposição (Figuras 2 e 3). 


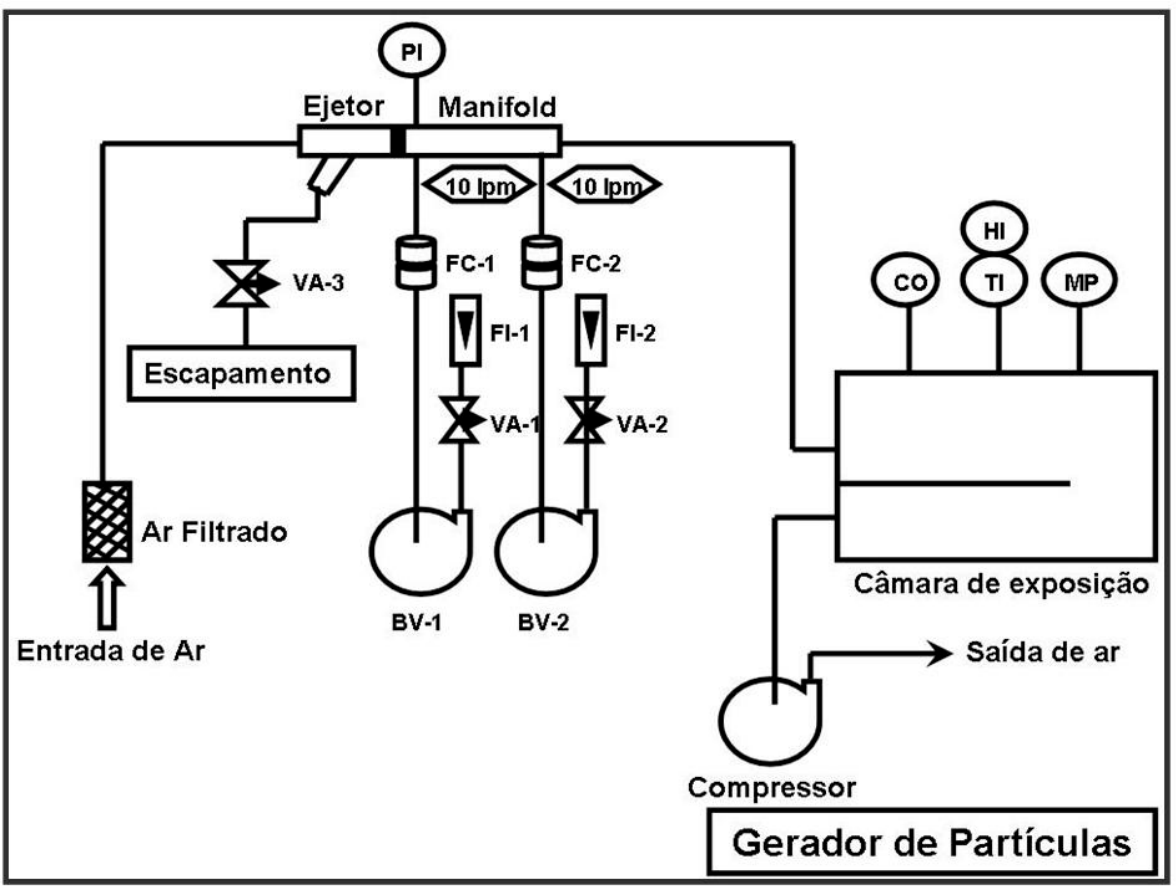

Figura 2. Gerador de partículas do material da exaustão dos combustíveis diesel-biodiesel

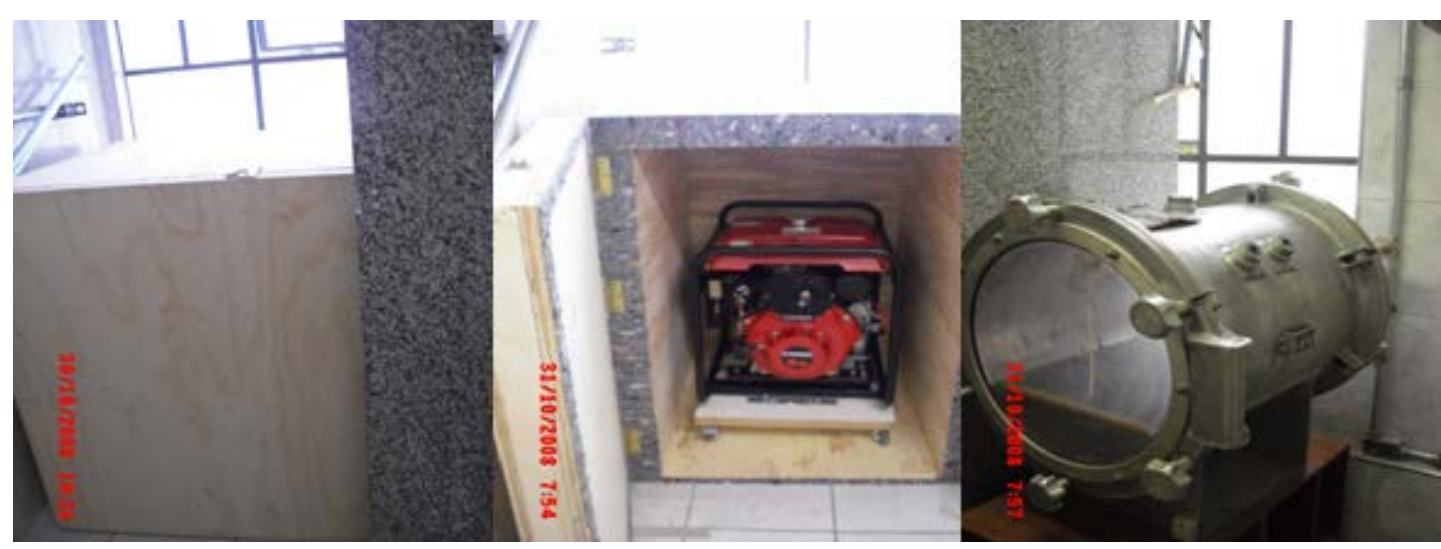

Figura 3. $A$ - caixa redutora de ruído; $B$ - gerador a diesel dentro da caixa e $C$ - câmara de intoxicação para roedores

Os gases resultantes do processo de combustão, ocorridos no gerador portátil estacionário, são conduzidos até uma câmara onde os camundongos Swiss são alocados de maneira a proceder à exposição de intoxicação como previsto no protocolo específico. Para reduzir a dosagem de intoxicação 
comparável a sobrevivência do animal e garantir o controle da concentração do gás nessa câmara, foi incluído um sistema de diluição do poluente, instalado junto a câmara de exposição, cuja regulagem é efetuada pela leitura de um medidor contínuo de concentração de MP na fração fina (MP2,5) (TrakPro versão 3.6.1.0, EUA) durante o experimento, servindo ainda para estimar a carga de MP ao qual o animal seria submetido. Desta forma, concomitante a queima do combustível, o sistema de purificação capta o ar ambiente, filtrandoo em $98 \%$ e direcionando-o ao ejetor com o intuito de diluição dos gases resultantes do material da exaustão e de preservação da ventilação adequada do gerador a diesel. Este sistema de filtração possibilitou que o grupo controle fosse submetido às mesmas condições experimentais descritas para o grupo diesel, com o diferencial quanto à inalação, que foi realizada somente com o ar filtrado que adentrava a câmara, sem a combustão do diesel, através do fechamento da válvula de abertura dos gases (Figura 4).

Cada sistema de coleta de amostra é composto por uma bomba a vácuo, um medidor de vazão de gás, uma válvula de agulha para regulagem do fluxo e um sistema de captura de material ou gás (filtro membrana, PUF e outros meios adequados a cada processo).

Os parâmetros monitorados em tempo real foram a temperatura e umidade relativa através de um termohigrômetro digital (modelo DHT -2000, Brasil), em intervalos de 3 minutos, emissões de CO (ToxyPro), nível de ruído, manualmente, em intervalos de 15 minutos através de decibelímetro digital (modelo IURDEC-420, Instrutemp, São Paulo, Brasil), concentração de material particulado fino $\left(\mathrm{MP}_{2.5}\right)$ (TrackPro versão 3.6.1.0 EUA) e 
composição volátil resultante da combustão do combustível, através de filtro mecânico e químico (modelo ECU-100, Purafil, EUA).

Para a detalhamento da composição do material particulado presente no ar filtrado e no ar da combustão do diesel, foi utilizado impactadores de pequeno volume, operando a uma vazão de 10L/min, por um período de 60 minutos em filtros de policarbonato Isopore $^{\mathrm{TM}}$, Membrane Filters Polycarbonate, $0.8 \mu \mathrm{m}, 37 \mathrm{~mm}$, Millipore, EUA) para a caracterização elementar das partículas e em filtros de Teflon $^{\text {TM }}$ (PTFE Membrane W;PMP Ring $2.0 \mu \mathrm{m}, 37 \mathrm{~mm}$, Energética, Brasil) para a caracterização dos hidocarbonetos policíclicos aromáticos (HPAs).

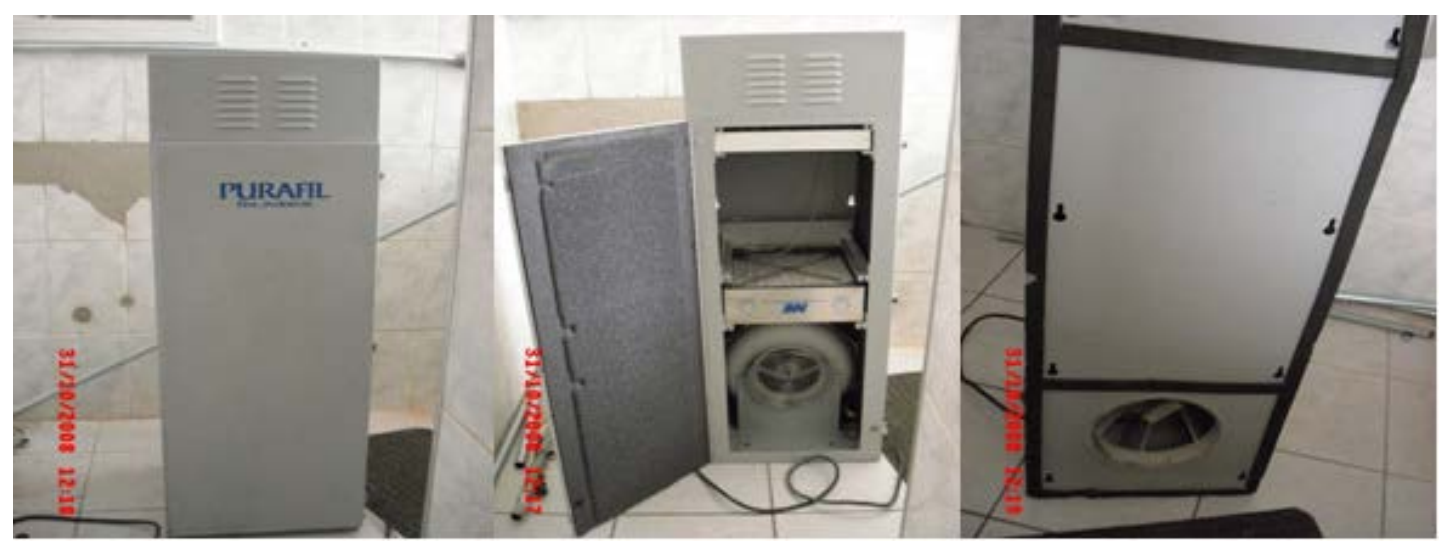

Figura 4. Sistema de filtragem de ar

Uma amostragem pontual do ar filtrado a 98\% (controle) e do ar da queima do diesel (exposto) foi realizada imediatamente na saída da câmara de exposição, em globos de aço inox de 6 litros (canister), a um fluxo de 50L/min, por um per[iodo de 60 minutos, para posterior análise de (COVs).A metodologia de amostragem dos compostos orgânicos voláteis (COVs) foi baseada nos métodos do TO-14 e TO-15 da EPA (EPA, 1999a; 1999b). 
Antes de introduzir os animais na câmara de exposição, o gerador ficava em funcionamento por 25 minutos com o intuito de estabilizar doses de exposição no caso dos grupos expostos à combustão do diesel ou para limpar o circuito no caso de exposições a ar filtrado.

\subsubsection{Caracterizações da exposição}

O propósito deste estudo foi de analisar os efeitos da exposição crônica ao diesel sobre o aparelho reprodutor feminino, sob uma concentração de exaustão do diesel dentro do permitido pela Comissão Nacional de Meio Ambiente (CONAMA) e dentro do limite máximo de média diária recomendável pela Organização Mundial da Saúde (WHO 2005) (25 $\mu \mathrm{g} / \mathrm{m}^{3}$ ), porém acima do limite anual.

Os animais foram expostos a uma concentração de $600 \mu \mathrm{g} / \mathrm{m}^{3}$ de material particulado fino por um período de 1 hora, diariamente, o que corresponderia a uma exposição crônica a $25 \mu \mathrm{g} / \mathrm{m}^{3}, 24$ horas por dia.

\subsubsection{Desenho do estudo}

O estudo foi realizado com camundongos da linhagem Swiss provenientes do Centro Multidisciplinar para Investigação Biológica (CEMIB) da Universidade de Campinas, São Paulo. 
Os animais permaneceram sem manipulação por quatro dias após sua chegada ao Laboratório experimental de poluição atmosférica da FMUSP com fins de eliminação do estresse causado pelo transporte. Durante todo o experimento, permaneceram sob controle de temperatura e umidade, ciclos de luz de 12/ 12 horas e com água e alimentação ad libitum.

A figura 5 demonstra a formação dos grupos de estudo. Dez fêmeas e 10 machos foram divididos em dois grupos iguais. Cinco casais compuseram o grupo exposto a ar filtrado (C) diariamente no gerador e 5 casais formaram o grupo exposto à combustão do diesel (E). Foi permitido o cruzamento por dois ciclos estrais. A gravidez foi confirmada pela presença do tampão mucoso vaginal (dia zero de gestação). Os machos foram removidos do estudo, bem como as fêmeas não-prenhas. As fêmeas prenhas foram expostas ao ar filtrado da câmara de exposição do gerador ou à combustão do diesel na câmara do gerador, diariamente, durante toda a gestação.

\section{Grupos experimentais}

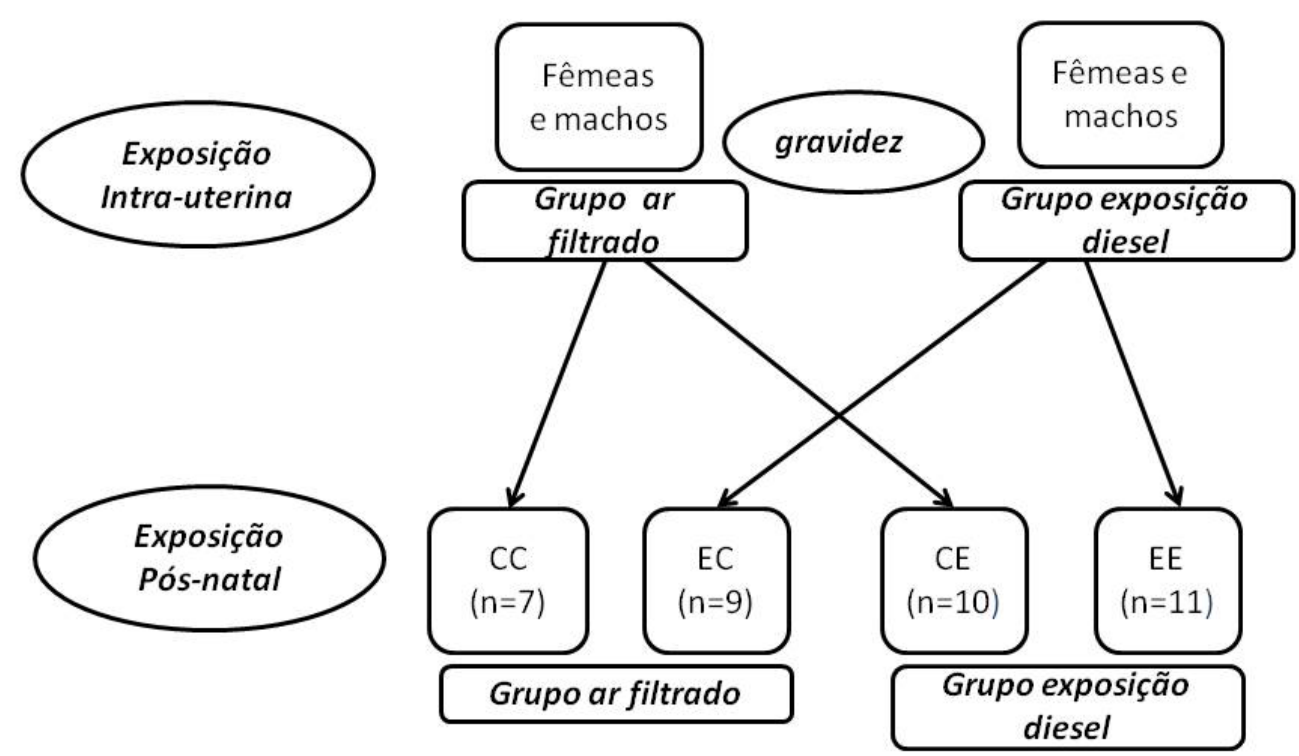

Figura 5. Ilustração esquemática dos grupos de estudo 
Após o nascimento das ninhadas, os filhotes permaneceram com a mãe durante o período de lactação. Após o desmame, as mães e os filhotes machos foram retirados do estudo. Metade das fêmeas que estiveram, durante o período intra-uterino expostas ao ar filtrado, passou a ser exposta à combustão do diesel até atingir a maturidade sexual (60 dias de vida), e a outra metade permaneceu sendo exposta ao ar filtrado até completar 60 dias de vida. Da mesma forma, metade dos filhotes fêmea que foi exposta à combustão do diesel durante a vida intra-uterina, passou a ser exposta ao ar filtrado até atingirem a maturidade sexual, e a outra metade, permaneceu sendo exposto à combustão do diesel até os 60 dias de vida.

Assim, formaram-se quatro grupos de estudo (Figura 5):

Grupo 1= exposição intra-uterina e pós-natal a ar filtrado (CC, n=7);

Grupo 2= exposição à combustão do diesel no período intra-uterino e a ar filtrado no período pós-natal (EC $n=9)$;

Grupo 3= exposição a ar filtrado no period intra-uterino e expoisão à combustão do diesel no período pós-natal (CE $n=10)$;

Grupo 4= exposição à combustão do diesel nos períodos intra-uterino e pósnatal (EE $n=11)$.

Os camundongos foram sacrificados aos 60 dias de vida, todos durante o estro para a coleta dos ovários e útero. Os animais foram submetidos a anestesia intraperitoneal ( 2-2-tribromoethanel - Sigma Aldrich - 0,02 mL/g ) (Nagy et al., 2003) e subseqüentemente secção aórtica.

Os ovários e o útero foram dissecados para análise histológica. 


\subsection{Análises dos componentes do diesel}

3.2.1 Análise do material particulado fino $\left(\mathrm{MP}_{2.5}\right)$ da exaustão do diesel: gravimetria, reflectância e espectrometria de fluorescência de raio-X (FRX)

Após a amostragem de material particulado fino em filtros de policarbonato (Isopore ${ }^{\mathrm{TM}}$ Membrane Filters Polycarbonate, 0,8 $\mu \mathrm{m}, 37 \mathrm{~mm}$, Millipore, EUA), a determinação da massa (concentração de partículas) foi realizada pelo método de gravimetria em uma balança ultra-micro analítica (modelo UMXZ, Metter e Toledo, Suíça). Em seguida, fez-se a medição da concentração de fuligem (carbono negro) presente nos filtros de policarbonato pela técnica de reflectância consiste na incidência de luz de uma lâmpada de tungstênio no filtro amostrado, que reflete uma intensidade inversamente proporcional a quantidade de carbono elementar presente na amostra, ou seja, quanto maior a quantidade de carbono elementar no filtro, menor a intensidade de luz refletida pelo filtro e menor a detecção pelo fotosensor.

Posteriormente, a caracterização elementar do $\mathrm{MP}_{2.5}$ foi determinada pelo método de espectofotometria de fluorescência de raio-x por dispersão de energia (FRX-DE) (modelo EDX 700HS, Shimadzu Corporation Analytical Instruments Division, Kyoto, Japão). A medição consiste na excitação dos elementos da amostra com raios- $X$, os quais tendem a ejetar os elétrons no interior dos níveis dos átomos, e assim, elétrons dos níveis mais afastados realizam um salto quântico preenchendo a vacância. Em cada salto, o 
elétron perde energia e esta energia é emitida em forma de um fóton de raios-X, de energia característica e bem definida para cada elemento, representados através de linhas espectrais. A área percorrida pelo raio-X foi de $10 \mathrm{~mm}$ para todas as amostras e foram realizadas três varreduras para cada filtro. Os elementos químicos passíveis de serem determinados foram: magnésio (Mg), alumínio (Al), silício (Si), fósforo $(P)$, enxofre $(\mathrm{S})$, cloro $(\mathrm{Cl})$, potássio $(\mathrm{K})$, cálcio $(\mathrm{Ca})$, titânio $(\mathrm{Ti})$, vanádio $(\mathrm{V})$, cromo $(\mathrm{Cr})$, manganês $(\mathrm{Mn})$, ferro $(\mathrm{Fe})$, níquel $(\mathrm{Ni})$, cobre $(\mathrm{Cu})$, zinco $(\mathrm{Zn})$, selênio $(\mathrm{Se})$, bromo $(\mathrm{Br})$, e chumbo $(\mathrm{Pb})$.

\subsubsection{Análise de hidrocarbonetos policíclicos aromáticos no material particulado}

Os solventes classificados pelo HPLC usados neste estudo foram: nhexano (HEX), acetona (ACT) e acetonitrila (ACN) (J.T. Baker, EUA). Uma solução de mistura padrão de 13 HPAs foi preparada de acordo com o padrão sólido para cada HPA: fenantreno (FEN), antraceno (ANT), fluoranteno (FLR), pireno (PYR), benzo[a]antraceno (BaA), criseno (CRY), benzo[k]fluoranteno (BkF), benzo[a]pireno (BaP), benzo[e]pireno (BeP), dibenzo[a,h]antraceno (DahA), benzo[e]acefenantrileno (BeAcf), benzo[g,h,i]perileno (BghiP), indeno[1,2,3-cd]pireno (IND). Os padrões de HPAs sólidos (pureza > 98\%) foram obtidos pelo Dr. Ehrenstorfer GmbH (Augsburg, Alemanha), exceto o benzo[k]fluoranteno (BkF) e o benzo[g,h,i]perileno (BghiP) que foram obtidos pela Sigma-Aldrich Brasil Ltda. 
A extração dos HPAs foi executada por um banho ultra-sônico (10 minutos), usando a mistura de $10 \mathrm{~mL}$ acetona: hexano (1:1, v/v) em três tempos. Em seguida, o volume extraído foi reduzido por um evaporador rotativo e seco em baixo fluxo de nitrogênio $\left(\mathrm{N}_{2}\right)$. O resíduo foi dissolvido em $1000 \mu \mathrm{L}$ de acetonitrila e analisado pelo HPLC/ Fluorescência (LC920, Varian, Riacho de Noz, EUA). Uma coluna de HPA Supelcosil LC (250 mm x 4,6 $\mathrm{mm} \times 5 \mu \mathrm{m}$ - Supelco, Bellefonte, EUA) foi usada. A fase móvel foi a acetonitrila/ água em modo de gradiente: acetonitrila $60 \%$ por 5 minutos, que foi usado com um gradiente linear até $100 \%$ de acetonitrila (20 minutos), e esta condição permaneceu por 10 minutos. A temperatura da coluna, volume de injeção e fluxo de fase móvel foram, respectivamente, $30{ }^{\circ} \mathrm{C}, 50 \mu \mathrm{L}$ e 1,8 $\mathrm{mL} / \mathrm{min}$. O detector de fluorescência foi operado com um programa de comprimento de onda.

A precisão do método de extração foi avaliada usando o certificado de referência INPT CRM-1649a (poeira urbana). A recuperação dos HPAs variou de 65 a $108 \%$ com RSD < 10\%, para todos os compostos.

\subsubsection{Analise da fração orgânica volátil e composição gasosa}

Foram utilizados dois equipamentos para a análise dos COVs. Um cromatógrafo gasoso (VARIAN 3800) com detecção simultânea de espectrometria de massas (SATURN 2000) para a identificação dos compostos e ionização de chama para quantificação dos compostos. Este 
sistema possui um método para análise de COVs que tenham no mínimo quatro carbonos. Outro método foi desenvolvido no Laboratório de Química Atmosférica (LQA) para COVs leves (2 a 5 carbonos), sendo que sistema utiliza um cromatógrafo (VARIAN 3800) acoplado com detector de ionização de chama.

A amostra foi analisada diretamente na fase gasosa, utilizando préconcentração criogênica, para possibilitar a análise de um grande volume de amostra (150-200 mL). Para os COVs com mais de 4 carbonos foi utilizada uma coluna apolar, de $60 \mathrm{~m}$ de comprimento, $1 \mu \mathrm{m}$ de espessura de fase estacionária e 0,32 mm de diâmetro interno. A programação utilizou uma variação de temperatura de $6^{\circ} \mathrm{C}$ min, de $-50^{\circ} \mathrm{C}$ a $200^{\circ} \mathrm{C}$. No final da coluna cromatográfica, a amostra foi dividida para dois detectores diferentes. Uma parte foi enviada para o Detector de Espectrometria de Massas (SATURN 2000) e outra para o Detector de Ionização de Chama, utilizando-se uma conexão em "T" de volume morto "zero" da Valco, compensando-se o vácuo do Detector de Detector de Espectrometria de Massas e a pressão atmosférica do Detector de Ionização de Chama.

No método para a quantificação dos COVs leves foi utilizado uma coluna PLOT de sílica fundida de $\mathrm{Al}_{2} \mathrm{O}_{3} / \mathrm{Na}_{2} \mathrm{SO}_{4}$ (polar) com $50 \mathrm{~m}$ de comprimento e 0,53 $\mathrm{mm}$ de diâmetro interno e $10 \mu \mathrm{m}$ de espessura de fase estacionária. A etapa da pré-concentração é igual a do método descrito anteriormente, a diferença está na utilização de uma coluna apropriada para COVs leves. A rampa de temperatura utilizada foi de $10^{\circ} \mathrm{C} / \mathrm{min}$, na faixa de $50^{\circ} \mathrm{C}$ a $180^{\circ} \mathrm{C}$. A detecção foi realizada com ionização de chama. 
A quantificação dos HC foi realizada utilizando-se de quatro misturas de padrões gasosos produzidos e certificados pela SCOTT SPECIALIST com a utilização de curvas de calibração de padrões certificados. As misturas padrões gasosas utilizadas foram: alcanos, alcenos, aromáticos e TO-14, de aproximadamente 1,0 ppmv, balanceados em nitrogênio.

Para a quantificação de compostos não contidos nos padrões, foram utilizados os fatores de resposta dos compostos de mesma família como alcans, alcenos e aromáticos. O fator de resposta é a razão entre a área obtida no cromatograma, dividido pela concentração, multiplicada pelo número de carbonos do composto em questão. As amostras foram analisadas em duplicata quando se verificava que a diferença de resposta entre as áreas encontradas era menor que 5\%, caso contrário, realizava-se a triplicata. Foram encontrados 70 picos nos cromatogramas, utilizando como critério à integração de picos com sinal superior a 400 contagens.

\subsection{Análise da toxicidade nos órgãos reprodutivos}

A ciclicidade estral foi avaliada nos camundongos após 45 dias de vida. Os camundongos receberam lavado vaginal diário com solução salina, entre às 8 horas e 9 horas da manhã por duas semanas ininterruptas. A ciclicidade estral foi definida como o número de eventos de proestro a estro durante o período de análise e o total de dias em estro exibido por cada 
animal (Holson, et al., 2005). Os lavados vaginais foram avaliados por microscópico ótico comum para a classificação dos estágios do ciclo estral considerando a proporção relativa de células epiteliais cornificadas, células epiteliais nucleadas e leucócitos, demonstrado na tabela 1. Um examinador cego para os grupos de estudo avaliou os esfregaços (Tabela 1).

Tabela 1. Classificação dos estágios do ciclo estral através da análise celular dos lavados vaginais

\begin{tabular}{lccc}
\hline Estágio do ciclo estral & \multicolumn{3}{c}{ Proporcão de células (\%) } \\
\cline { 2 - 4 } & $\begin{array}{c}\text { Células } \\
\text { cornificadas }\end{array}$ & $\begin{array}{c}\text { Células epiteliais } \\
\text { nucleadas }\end{array}$ & Leucócitos \\
\hline Diestro & 0 & $>60$ & $\leq 10$ \\
Proestro & $\geq 60$ & $\geq 20$ \\
Metaestro & $\geq 90$ & 0 \\
Estro & & & 0 \\
\hline
\end{tabular}

Os ovários e útero de cada animal foram dissecados, depositados em paraformaldeído por 48 horas e após, transferidos para álcool 70\%, para posterior preparo histológico. Os órgãos foram emblocados em parafina e secções de $5 \mu \mathrm{m}$ de espessura foram preparados e dispostos em lâminas, corados com hematoxilina-eosina (HE). Os cortes dos ovários direito e esquerdo de cada animal foram dispostos em duas fileiras separadas na mesma lâmina e o útero foi disposto na lâmina em corte longitudinal.

A análise histológica morfométrica foi realizada utilizando microscópio óptico comum para determinar a área relativa ocupada por cada estrutura. $A$ 
morfometria foi realizada através da contagem de pontos na estrutura a ser quantificada, dentro da área do retículo de 100 pontos, dividindo o numero de pontos na determinada estrutura, pelo total de pontos do retículo (Lanças et al., 2006). As estruturas ovarianas quantificadas foram os folículos primordiais, primários, secundários, folículos de Graaf, corpos lúteos e estroma ovariano (Tilly, 2003). As estruturas uterinas foram quantificadas com a mesma técnica e as estruturas quantificadas foram o epitélio endometrial, estroma endometrial e glândulas endometriais. As mensurações foram realizadas contando em 10 campos não-sobrepostos com magnificação de 100x. Os resultados foram expressos em volume proporcional. A análise das lâminas foi realizada pelo mesmo observador e a leitura foi cega para os grupos em estudo.

\subsection{Análise Estatística}

As análises foram realizadas usando o pacote estatístico "Statistical Package for the Social Sciences (SPSS)" versão 15; Inc ${ }^{\circledR}$, Chicago, II. A distribuição normal foi avaliada através do teste de Kolmogorov-Smirnov. A comparação das concentrações de $\mathrm{PM}_{2.5}$ e $\mathrm{BC}$ nos grupos expostos ao ar filtrado e ao diesel foi realizado usando teste T. Os resultados da análise das morfologias foram alcançados através da análise de variância (ANOVA) considerando as condições independentes de exposição, durante a vida 
intra-uterina ou pós-natal, assim como a interação entre as duas situações. O teste de comparações múltiplas entre as médias foi o teste de Turkey. O nível de significância foi adotado foi de 5\%. 
4 Resultados

= 


\subsection{Análises dos parâmetros de exposição em tempo real}

A tabela 2 demonstra a estatística descritiva da concentração de CO (monóxido de carbono), temperatura, umidade relativa e de ruído nas câmaras de exposição durante o experimento. Foi demonstrado um aumento significativo na concentração de monóxido de carbono nos grupos exposto ao diesel, comparado aos grupos expostos ao ar filtrado $(p<0,001)$. A temperatura e a umidade relativa foram semelhantes entre os grupos (controle e diesel). O nível de ruído nas câmaras de exposição ao diesel foi maior comparado ao nível de ruído nos grupos controle $(p<0,05)$, porém não atingiram níveis considerados traumáticos para os animais (Fowler et al., 1995).

Tabela 2. Estatística descritiva de CO, temperatura, umidade relativa e ruído nas câmaras de exposição de todos os grupos medidos em tempo real durante 1 hora de exposição

\begin{tabular}{|c|c|c|c|c|c|c|}
\hline \multirow[b]{2}{*}{ Parâmetros } & \multicolumn{2}{|c|}{ Intra-uterino } & \multicolumn{4}{|c|}{ Pós-natal } \\
\hline & Controle & Diesel & CC & EC & CE & EE \\
\hline & \multicolumn{2}{|c|}{ Média (DP) } & \multicolumn{4}{|c|}{ Média (DP) } \\
\hline Temp $\left({ }^{\circ} \mathrm{C}\right)$ & $22,14(2,41)$ & $31,05(133,88)$ & $22,62(1,83)$ & $22,54(1,90)$ & $23,01(2,88)$ & $23,02(2,88)$ \\
\hline Umidade R (\%) & $73,41(6,33)$ & $73,20(6,23)$ & $76,24(4,95)$ & $76,13(5,09)$ & $77,55(5,90)$ & $77,63(5,83)$ \\
\hline $\mathrm{CO}(\mathrm{ppm})$ & $0,66(1,30)$ & $9,14(11,27)^{a}$ & $0,82(1,83)$ & $0,86(1,91)$ & $42,80(38,32)^{b}$ & $43,92(38,19)^{b}$ \\
\hline Ruído (dB) & $63,40(2,29)$ & $68,09(4,38)^{a}$ & $66,17(3,69)$ & $66,33(3,84)$ & $68,32(4,07)^{b}$ & $68,15(4,14)^{b}$ \\
\hline
\end{tabular}

a Intra-uterino - Diesel $\neq$ grupo controle $(p<0,001)$

${ }^{b}$ Pós-natal- $C C, E C \neq C E, E E(p<0,05)$ 


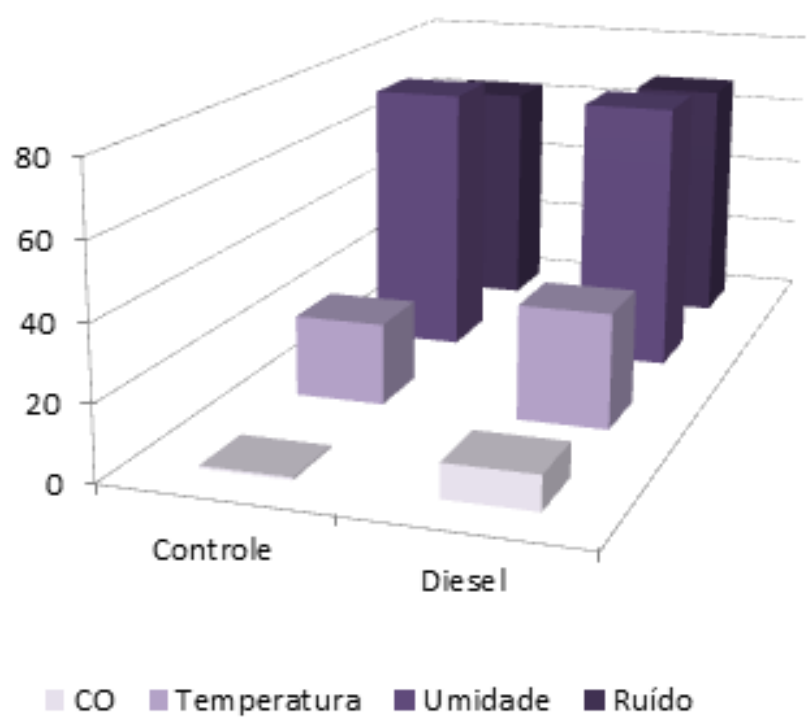

Figura 6. Representação gráfica dos parâmetros medidos em tempo real no período intrauterino

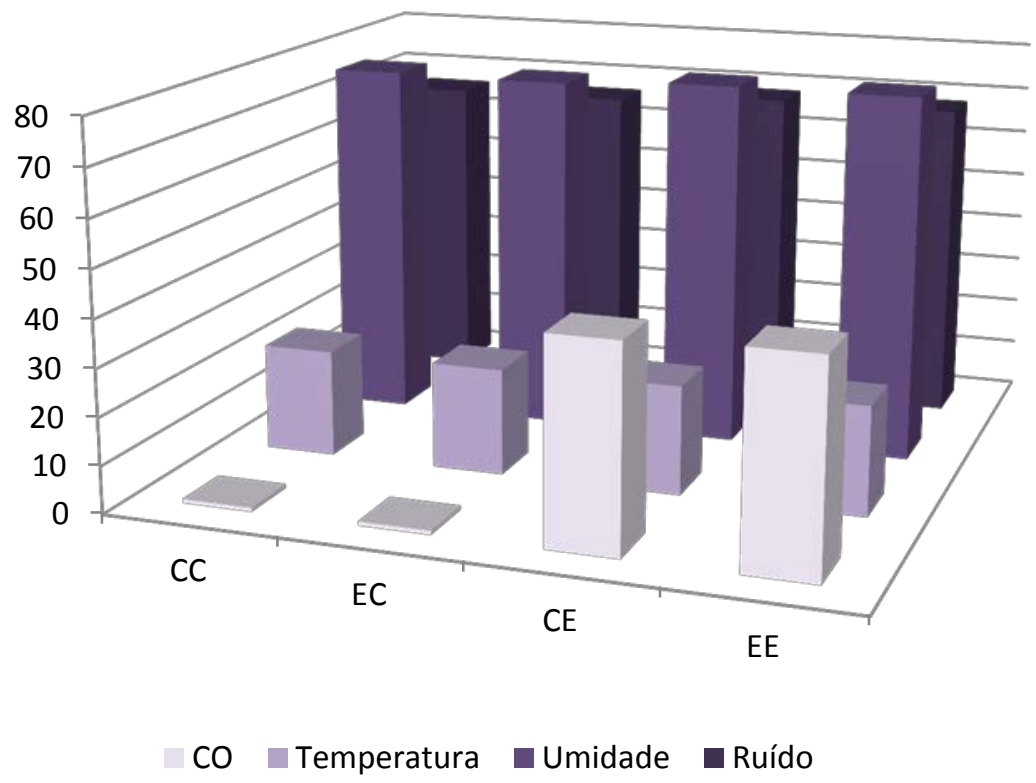

Figura 7. Representação gráfica dos parâmetros medidos em tempo real no período pósnatal 


\subsection{Análise do filtro de policarbonato}

\subsubsection{Quantificação do material particulado fino $\left(\mathrm{MP}_{2.5}\right)$ por gravimetria}

A concentração média de $\mathrm{MP}_{2.5}$ durante a exposição intra-uterina no grupo controle foi de $67,50 \mu \mathrm{g} / \mathrm{m}^{3}$, e no grupo exposto à combustão do diesel foi de $659,98 \mu \mathrm{g} / \mathrm{m}^{3}$ ( $\left.p<0,001\right)$. Estas doses correspondem a médias diárias de $2,66 \mu \mathrm{g} / \mathrm{m}^{3}$ e $27,91 \mu \mathrm{g} / \mathrm{m}^{3}$, respectivamente, sendo o segundo muito próximo a média diária máxima recomendada pelo OMS de 25 $\mathrm{g} / \mathrm{m}^{3}$ (WHO, 2005).

A concentração média de $\mathrm{MP}_{2.5}$ durante a exposição dos grupos no período pós-natal foi de $38,93 \mu \mathrm{g} / \mathrm{m}^{3}$ no grupo controle e de $515,6 \mu \mathrm{g} / \mathrm{m}^{3}$ no grupo exposto ao diesel $(p<0,001)$. Portanto, a dose média diária dos dois grupos foi de $1,62 \mu \mathrm{g} / \mathrm{m}^{3}$ e $21,48 \mu \mathrm{g} / \mathrm{m}^{3}$ respectivamente, ambos abaixo da dose média diária de exposição a MP fino recomendado pela OMS (WHO, 2005).

Os níveis de exposição ao material particulado do combustível ficaram muito próximos às concentrações diárias consideradas aceitáveis pela Organização Mundial da Saúde e acima da média anual recomendada, com diferenças significativas entre os grupos expostos ao ar filtrado e à combustão do diesel. Nos grupos expostos ao diesel, a concentração do combustível foi semelhante entre os períodos intra-uterino e pós-natal.

A duração média da gravidez foi de 19,46 \pm 0,66 nos grupos controle e de 19,53 \pm 0.77 nos grupos expostos a diesel, tempo de exposição este, três vezes menor que o tempo de exposição no período pós-natal (60 dias). 
A tabela 3 demonstra a estatística descritiva da concentração de material particulado presente no filtro a que os animais foram expostos nos diferentes grupos (Tabela 3).

\subsubsection{Quantificação do carbono negro por reflectância de luz}

Durante a exposição intra-uterina, a concentração média de carbono negro foi de $3,09 \mu \mathrm{g} / \mathrm{m}^{3}$ no grupo controle e de $99,61 \mu \mathrm{g} / \mathrm{m}^{3}$ no grupo exposto à queima do diesel $(p<0,001)$.

No período pós-natal, os níveis de carbono negro foram de 1,21 $\mu \mathrm{g} / \mathrm{m}^{3}$ nos grupos controle e de $119,66 \mu \mathrm{g} / \mathrm{m}^{3}$ nos grupos expostos ao diesel $(p<0,001)$.

A tabela 3 demonstra a estatística descritiva da concentração de carbono negro (fuligem) presente no filtro a que os animais foram expostos nos diferentes grupos (Tabela 3).

Tabela 3. Valores descritivos dos parâmetros mensurados nos filtros: material particulado e carbono negro. Os valores estão apresentados como média e desvio padrão

\begin{tabular}{|c|c|c|c|c|c|c|}
\hline \multirow[b]{2}{*}{$\begin{array}{l}\text { Parâmetros } \\
\left(\mu \mathrm{g} / \mathrm{m}^{3}\right)\end{array}$} & \multicolumn{2}{|c|}{ Intra-uterino } & \multicolumn{4}{|c|}{ Pós-natal } \\
\hline & Control & Diesel & $\mathrm{CC}$ & EC & CE & $\overline{\mathrm{EE}}$ \\
\hline & \multicolumn{2}{|c|}{ Média (DP) } & \multicolumn{4}{|c|}{ Média (DP) } \\
\hline MP & $67,50(51,37)$ & $659,98(554,42)^{a}$ & $38,93(33,60)$ & $38,93(33,60)$ & $512,97(143,27)^{b}$ & $518,23(130,39)^{b}$ \\
\hline $\mathrm{CN}$ & $3,09(10,08)$ & $99,61(52,50)^{a}$ & $1,21(0,97)$ & $1,21(0,97)$ & $119,66(66,60)^{b}$ & $119,66(66,60)^{b}$ \\
\hline
\end{tabular}

a Intra-uterino - Diesel $\neq$ grupo controle $(p<0,001)$

${ }^{b}$ Pós-natal- CC, EC $\neq C E, E E(p<0,001)$ 
Nos filtros de policarbonato dos grupos expostos ao diesel, foi possível verificar uma proporção de $15,09 \%$ de carbono negro para o total de material particulado durante as exposições intra-uterinas e de 23,20\% nas exposições pós-natais (Figura 8).

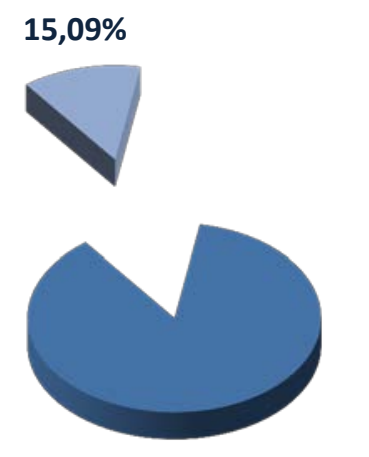

MP

Carbono

negro

\section{Período intra-uterino}

$23,20 \%$
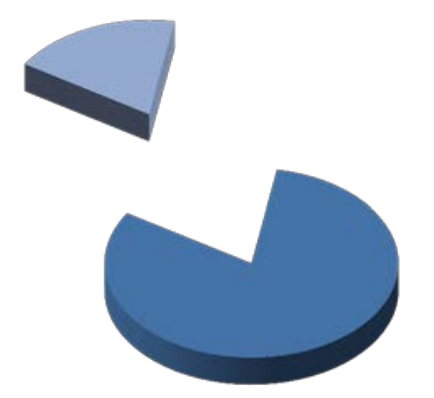

$\square \mathrm{MP}$

Carbono negro

Figura 8. Demonstração gráfica da proporção de carbono negro presente no material particulado dos grupos expostos ao diesel.

\subsubsection{Caracterização dos elementos inorgânicos do por espectrometria de fluorescência de Raio-X}

A análise da composição elementar presente no material particulado do filtro de policarbonato estão descritos na tabela 4.. Os dados comparam a quantificação dos elementos químicos (Mg, Al, Si, P, S, Cl, K, Ca, Ti, V, Cr, $\mathrm{Mn}, \mathrm{Fe}, \mathrm{Ni}, \mathrm{Cu}, \mathrm{Zn}, \mathrm{Se}, \mathrm{Br}, \mathrm{Pb})$ presentes durante as exposições dos grupos controles, expostos ao ar filtrado, e dos grupos expostos ao diesel. Os grupos expostos ao diesel mostraram um aumento nos elementos químicos $\mathrm{Pb}, \mathrm{Se}, \mathrm{Zn}, \mathrm{Fe}, \mathrm{Ca}, \mathrm{K}, \mathrm{S}$ e Mg comparado aos grupos controles (Tabela 4). 
Tabela 4. Valores descritivos dos compostos inorgânicos presentes durante a exposição. Os valores estão apresentados como média e desvio padrão.

\begin{tabular}{|c|c|c|}
\hline $\begin{array}{l}\text { Parâmetros } \\
\left(\mathrm{ng} / \mathrm{m}^{3}\right) \\
\end{array}$ & $\begin{array}{l}\text { Controle }(\mathrm{n}=10) \\
\text { Média (DP) }\end{array}$ & $\begin{array}{c}\text { Diesel }(n=22) \\
\text { Média (DP) }\end{array}$ \\
\hline $\mathrm{Mg}$ & $0,03(0,05)$ & $0,072(0,16)$ \\
\hline $\mathrm{Al}$ & $0,27(0,45)$ & $0,20(0,29)$ \\
\hline $\mathrm{Si}$ & $0,02(0,06)$ & $0,00(0,01)$ \\
\hline $\mathrm{P}$ & $0,03(0,09)$ & $0,01(0,01)$ \\
\hline $\mathrm{s}$ & $0,13(0,22)$ & $0,46(0,19)$ \\
\hline $\mathrm{Cl}$ & $0,01(0,02)$ & $0,01(0,03)$ \\
\hline K & $0,04(0,03)$ & $0,09(0,08)$ \\
\hline $\mathrm{Ca}$ & $0,03(0,06)$ & $0,06(0,06)$ \\
\hline $\mathrm{Ti}$ & $0,00(0,01)$ & $0,00(0,01)$ \\
\hline v & $0,01(0,01)$ & $0,01(0,01)$ \\
\hline $\mathrm{Cr}$ & ND & ND \\
\hline $\mathrm{Mn}$ & $0,00(0,01)$ & ND \\
\hline $\mathrm{Fe}$ & $0,01(0,02)$ & $0,05(0,04)$ \\
\hline $\mathrm{Ni}$ & $0,01(0,01)$ & $0,01(0,01)$ \\
\hline $\mathrm{Cu}$ & $0,02(0,04)$ & $0,02(0,03)$ \\
\hline $\mathrm{Zn}$ & $0,01(0,02)$ & $0,02(0,03)$ \\
\hline Se & $0,01(0,01)$ & $0,02(0,01)$ \\
\hline $\mathrm{Br}$ & $0,02(0,01)$ & $0,02(0,01)$ \\
\hline $\mathrm{Pb}$ & $0,01(0,01)$ & $0,02(0,02)$ \\
\hline
\end{tabular}

ND: não detectado 


\subsection{Análise dos filtros de Teflon}

\subsubsection{Caracterização dos hidrocarbonetos policíclicos aromáticos}

A análise dos filtros de Teflon confirmou concentrações médias totais de HPAs em concentrações significativamente maiores no material oriundo da queima do combustível diesel quando comparado ao material dos grupos controle, como disposto na tabela 5.

Tabela 5. Valores descritivos dos HPAs. Os valores estão apresentados como mínimos e máximos

\begin{tabular}{|c|c|c|c|c|}
\hline \multirow[b]{2}{*}{ Parameters $\left(\mathrm{ng} / \mathrm{m}^{3}\right)$} & \multicolumn{2}{|c|}{ Control $(n=6)$} & \multicolumn{2}{|c|}{ Diesel $(n=14)$} \\
\hline & Minimum & Maximum & Minimum & Maximum \\
\hline NAF & 0,27 & 0,35 & 4,57 & 149,78 \\
\hline ACE & \multicolumn{2}{|c|}{ ND } & \multicolumn{2}{|c|}{ ND } \\
\hline FENO & 21,88 & 51,07 & 745,8 & 2861,83 \\
\hline ANT & 1,63 & 6,65 & 29,33 & 92,58 \\
\hline FLR & 26,52 & 103,85 & 958,83 & 4402,02 \\
\hline PYR & 3,7 & 13,15 & 81,77 & 197,82 \\
\hline $\mathrm{BaA}$ & 1,87 & 14,32 & 99,18 & 321,2 \\
\hline CRY & 37 & 12 & 15,77 & 103,88 \\
\hline $\mathrm{BeACY}$ & 1,03 & 6,68 & 6,05 & 574,93 \\
\hline $\mathrm{B} k \mathrm{~F}$ & 0,05 & 0,43 & 7,33 & 87,63 \\
\hline $\mathrm{BaP}$ & 0,08 & 0,45 & 0,92 & 9,72 \\
\hline $\mathrm{BeP}$ & 0,7 & 23,78 & 19,62 & 811,98 \\
\hline DahA & 1,37 & 4,12 & 25,85 & 585,2 \\
\hline BghiP & 0,88 & 7,03 & 128,15 & 1803,82 \\
\hline$\Sigma \mathrm{PAHs}$ & 18,7 & 150,1 & 860,93 & 8019,55 \\
\hline
\end{tabular}

ND: não detectado 


\subsection{Análise da fração gasosa da exaustão do diesel}

\subsubsection{Identificação e quantificação de compostos orgânicos voláteis}

No processo de identificação dos COVs na amostragem pontual da fração volátil do ar filtrado e do material da exaustão do diesel foram detectados 97 compostos diferentes descritos na tabela 6.

Tabela 6. Valores de COVs mensurados através de amostras pontuais dos grupos expostos a ar filtrado e grupos expostos à exaustão do diesel

\begin{tabular}{lll}
\hline Concentração $\left(\boldsymbol{\mu g} / \mathbf{m}^{3}\right)$ & Controle & Diesel \\
\hline Aromáticos & & \\
Tolueno & 59,87 & 223,03 \\
p-xileno & 44,98 & 320,93 \\
1,2,4 trimetilbenzeno & 38,21 & 99,28 \\
Etilbenzeno & 26,48 & 216,38 \\
o-xileno & 26,22 & 182,42 \\
m-xileno & 22,65 & 180,88 \\
1-etil-4-metilbenzeno & 19,93 & 70,58 \\
1,3,5-trimetilbenzeno & 18,85 & 91,62 \\
1,2,3-trimetilbenzeno & 23,37 & 42,98 \\
1-metil-3-propilbenzeno & 11,65 & 22,71 \\
1-etil-3-metilbenzeno & 16,21 & 97,58 \\
Propilbenzeno & 10,61 & 89,61 \\
1-etil-2-metilbenzeno & 9,97 & 40,73 \\
Estireno & 13,63 & $\mathrm{ND}$ \\
Aromáticos & & \\
Isopropilbenzeno & 10,34 & 74,24 \\
Indano & 10,43 & 12,40 \\
1,2-dietilbenzeno & 10,34 & 4,74 \\
Benzeno & 63,89 & 33,75 \\
& &
\end{tabular}


Continuação Tabela 6

\begin{tabular}{|c|c|c|}
\hline Concentração $\left(\mu \mathrm{g} / \mathrm{m}^{3}\right)$ & Controle & Diesel \\
\hline \multicolumn{3}{|l|}{ Alcanos } \\
\hline Nonano & 44,83 & 636,37 \\
\hline Decano & 63,24 & 197,92 \\
\hline Undecano & 64,84 & 64,19 \\
\hline Metilcicloexano & 8,62 & 487,50 \\
\hline Octano & 14,11 & 689,73 \\
\hline Heptano & 5,28 & 373,72 \\
\hline 1,1,3-trimetilcicloexano & 12,90 & 478,12 \\
\hline 2-metil-heptano & 6,16 & 385,95 \\
\hline 1,2,4-trimetilcicloexano & 12,45 & 352,00 \\
\hline Trans-1,4-dimetilcicloexano & 6,29 & 364,73 \\
\hline Etilcicloexano & 8,74 & 325,39 \\
\hline Propano & 6,07 & 11,34 \\
\hline Ciclohexano & 2,71 & 86,93 \\
\hline 1-etil-2-metil-cicloexano & 13,67 & 176,99 \\
\hline Isopentano & 14,10 & 27,78 \\
\hline 3-metilhexano & 3,34 & 144,11 \\
\hline Trans-1-etil-3-metilcicloexano & 8,87 & 170,32 \\
\hline 1-metil-1-propilcicloexano & 13,81 & 35,73 \\
\hline Etano & 2,90 & 17,27 \\
\hline Trans-1,3-dimetilcicloexano & 4,84 & 207,06 \\
\hline Butano & 12,95 & 21,91 \\
\hline Hexano & 2,02 & 62,32 \\
\hline 1,3,5-trimetilcicloexano & 7,93 & 154,64 \\
\hline Metilciclopentano & 1,47 & 74,50 \\
\hline 2-metil-hexano & 1,31 & 92,59 \\
\hline 3-metil-heptano & 2,88 & 157,74 \\
\hline Cis-1,2-dimetilciclopentano & 2,25 & 156,16 \\
\hline \multicolumn{3}{|l|}{ Alcanos } \\
\hline Pentano & 4,11 & 27,88 \\
\hline 1,2,3-trimetilciclopentano & 1,72 & 137,27 \\
\hline Cis-1-etil-3-metil-ciclopentano & ND & 161,79 \\
\hline Etilciclopentano & 1,99 & 110,58 \\
\hline Cis-1-etil-4-metil-cicloexano & 5,25 & 103,75 \\
\hline Cis-1,3-dimetilciclopentano & 1,63 & 80,09 \\
\hline Cis-1,4 -dimetilcicloexano & 2,44 & 115,03 \\
\hline 1,2,4 - trimetilciclopentano & 1,39 & 96,71 \\
\hline Trans-1,3-dimetilciclopentano & 1,00 & 66,62 \\
\hline
\end{tabular}

Continua... 
Continuação Tabela 6

\begin{tabular}{|c|c|c|}
\hline Concentração $\left(\mu \mathrm{g} / \mathrm{m}^{3}\right)$ & Controle & Diesel \\
\hline 2-metilpentano & 1,54 & 29,29 \\
\hline Cis-1,3-dimetilcicloexano & 2,33 & 114,72 \\
\hline 2,3-dimetilpentano & 1,05 & 54,57 \\
\hline Isobutano & 2,91 & 6,06 \\
\hline 2,3-dimetil-hexano & 1,13 & 76,97 \\
\hline 3-metilpentano4 & 1,51 & 15,70 \\
\hline 1,1,3 - trimetilciclopentano & 1,29 & 44,96 \\
\hline 1,2,3 - trimetilcicloexano & 0,85 & 44,51 \\
\hline Butilciclopentano & 0,88 & 45,72 \\
\hline 1,1-dimetilciclopropano & 0,90 & 7,41 \\
\hline Ciclopentano & ND & 5,35 \\
\hline 1,1-dimetilciclopentano & ND & 15,90 \\
\hline 2,2-dimetilbutano & ND & ND \\
\hline 2-metiloctano & ND & ND \\
\hline 4-metil-octano & ND & 302,43 \\
\hline \multicolumn{3}{|l|}{ Alcenos } \\
\hline Eteno & 4,00 & 558,25 \\
\hline 1-buteno & 1,52 & 97,72 \\
\hline Propeno & 1,23 & 291,88 \\
\hline Trans-2-penteno & 2,10 & 10,12 \\
\hline 3-etil-ciclopenteno & ND & ND \\
\hline \multicolumn{2}{|c|}{ Trans-1-etil-3-metil-ciclopentano2,92 } & ND \\
\hline 2-metil-2-buteno & 2,20 & 13,81 \\
\hline \multicolumn{3}{|l|}{ Alcenos } \\
\hline 2-penteno-4metil & 0,53 & ND \\
\hline Cis-2-penteno & 0,75 & 5,02 \\
\hline 4-metil-2-penteno & ND & ND \\
\hline Trans-2-buteno & ND & 10,05 \\
\hline Cis-2-buteno & ND & 9,80 \\
\hline 1-penteno & 0,28 & 9,84 \\
\hline Ciclopenteno & ND & 7,84 \\
\hline 3-metil-1-buteno & ND & 7,32 \\
\hline 2-metil-1-penteno & ND & 23,15 \\
\hline Hexeno & ND & 16,57 \\
\hline 3-metilciclopenteno & ND & 4,65 \\
\hline
\end{tabular}

Continua... 
Conclusão Tabela 6

\begin{tabular}{lll}
\hline Concentração $\left(\boldsymbol{\mu g} / \mathbf{m}^{3}\right)$ & Controle & Diesel \\
\hline 1-metilciclopenteno & ND & 5,33 \\
3-hepteno & 0,99 & ND \\
3-hexeno-3-metil & ND & 2,20 \\
4-octeno & ND & ND \\
2,6-dimetil-4-octeno & ND & 59,31 \\
Alcadienos & & \\
Isopreno & 1,99 & 19,27 \\
1,3-butadieno & ND & 81,27 \\
But-1-eno-3-ino & ND & 6,72 \\
Pent-3-en-1-ino & ND & 20,89 \\
$\Sigma$ CoVs & $\mathbf{7 7 5 , 2 9}$ & $\mathbf{1 0 7 1 6 , 9 4}$ \\
\hline
\end{tabular}

ND: não detectado

Observou-se que houve maior emissão de COVs no grupo exposto ao diesel, comparado ao grupo exposto ao ar filtrado. A figura 9 demonstra os valores da concentração total dos COVs amostrados (Figura 9).

\section{COVs}

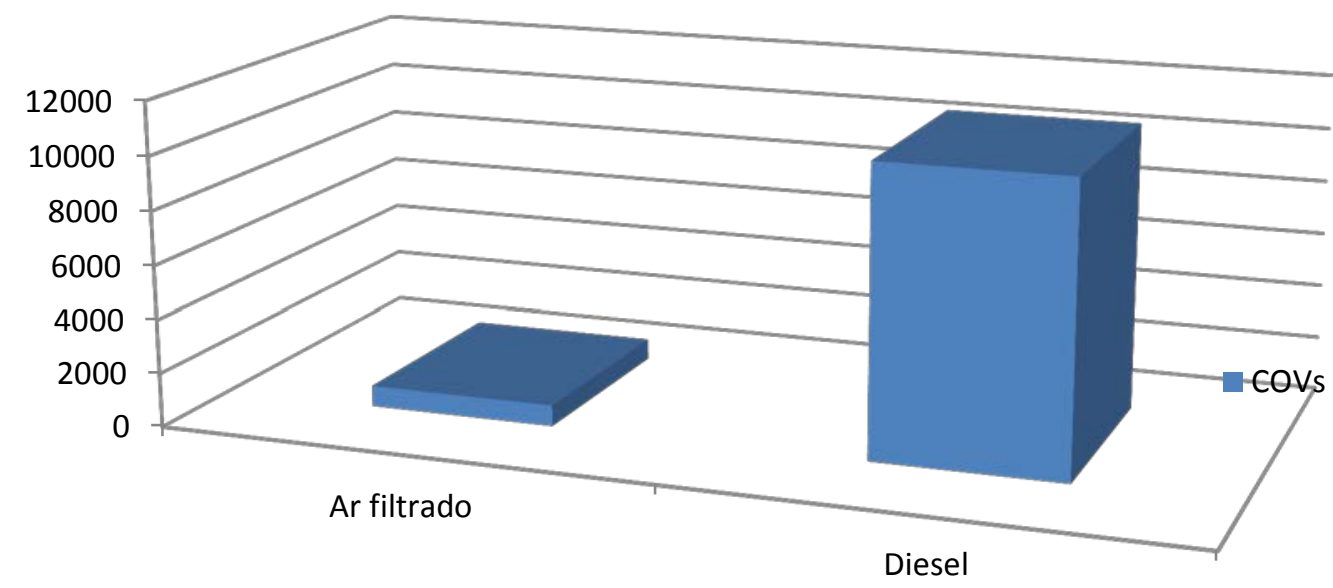

Figura 9. Demonstração de valores pontuais da concentração total dos COVs amostrados nos grupos controle e exposto a diesel 
Dentre os compostos orgânicos voláteis presentes nas amostragens dos grupos, foi possível observar um predomínio de alcanos, muito evidente no grupo exposto a diesel, e com predomínio proporcionalmente menor, no grupo exposto ao ar filtrado (Figura 10).

A tabela 7 apresenta a estatística descritiva dos diferentes grupos de COVs presentes nas amostras.

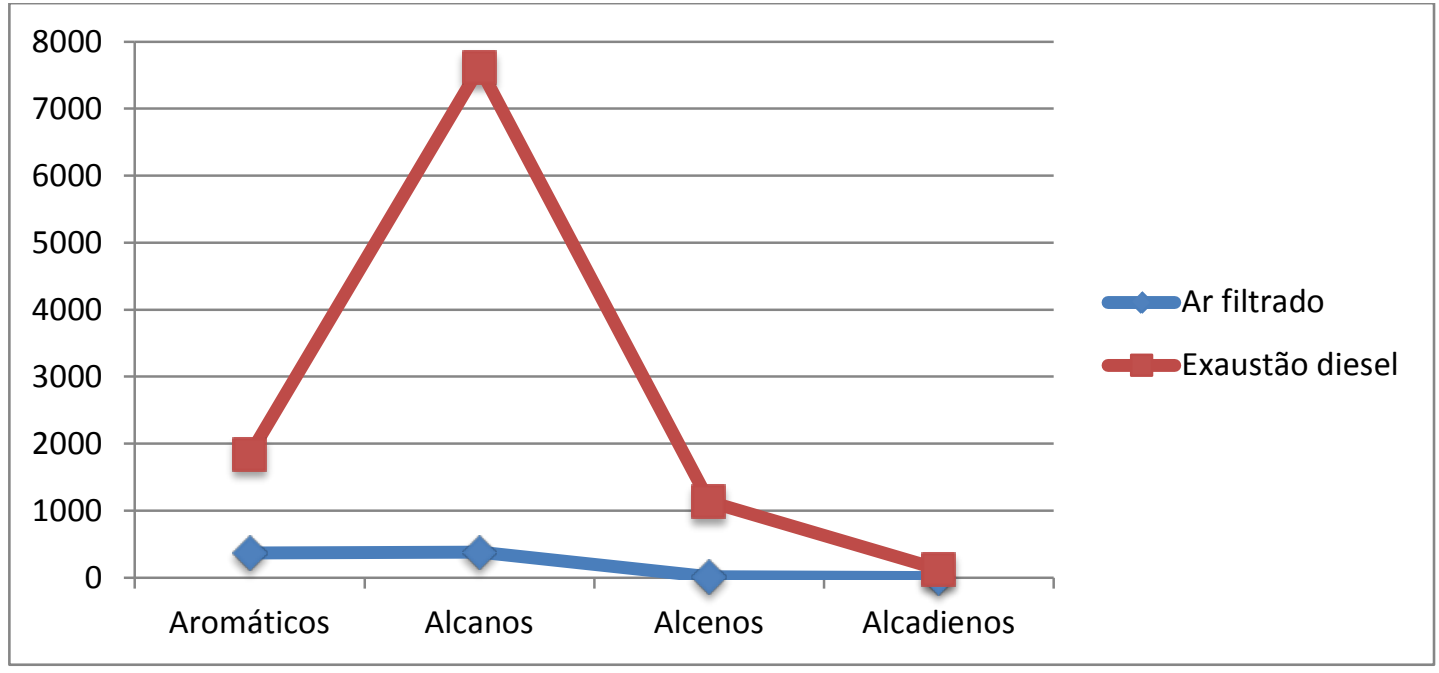

Figura10. Composição dos COVs nos grupos expostos a ar filtrado e a diesel

Tabela 7. Estatística descritiva dos compostos orgânicos voláteis (aromáticos, alcanos, alcenos, alkadienos) para todas as amostras. Os resultados estão expressos em valores mínimos, máximos e a soma dos compostos na amostra

\section{Controle}

Parâmetros

$\left(\mu \mathrm{g} / \mathrm{m}^{3}\right)$

Aromáticos

Alcanos

Alcenos

Alcadienos

$$
\text { min }
$$

1,2

$\max$

$$
\text { soma }
$$

368,75

64,84

382,50

16,52

2

\section{Diesel}

\begin{tabular}{lll}
\hline $\min$ & $\max$ & soma \\
0 & 320,93 & 1839,6 \\
0 & 689,73 & 7616,32 \\
0 & 558,25 & 1132,86 \\
6,72 & 81,27 & 128,15
\end{tabular}

min=mínimo, $\max =$ máximo 
Especificando, os seguintes compostos orgânicos voláteis foram encontrados em concentrações aumentadas nas amostras:

Ar filtrado (controle): undecano, decano, tolueno, p-xileno, nona no, 1,2,4 trimetilbenzeno, etilbenzeno, 0-xileno, 1,2,3-trimetilbenzeno, m-xileno, 1-etil4-metilbenzeno, 1,3,5 trimetilbenzeno, 1-etil-3-metilbenzeno, octano, isopentano.

Diesel: octano, nonano, eteno, metilcicloexano, 1,1,3-trimetilcicloexano, 2metil-heptano, heptano, trans-1,4-dimetilcicloexano, 1,2,4-trimetilcicloexano, etilcicloexano, p-xileno, 4-metil-octano, propeno, tolueno, etilbenzeno.

\subsection{Parâmetros reprodutivos}

Dos cinco casais em cada grupo, a taxa de gravidez foi de $80 \%$ no grupo exposto a ar filtrado e de $80 \%$ no grupo exposto ao diesel. Após o período de exposição intra-uterina, um total de 46 filhotes nasceu do grupo controle e 54 filhotes do grupo exposto a diesel. Do grupo controle, 47,82\% da ninhada foram representadas por fêmeas e do grupo exposto, 46,29\%. Após o nascimento, as fêmeas de cada grupo foram subdivididas nos quatro grupos de estudo descritos anteriormente. 


\subsubsection{A ciclicidade estral}

A tabela 8 apresenta a estatística descritiva da análise da ciclicidade dos animais ao longo do experimento. Não foi encontrada diferença significativa para a duração do estro ou para eventos de proestro para estro em nenhum dos grupos (Tabela 8).

Tabela 8. Valores descritivos da ciclicidade analisada dos quatro grupos

\begin{tabular}{lcccl}
\hline Parâmetros & CC & EC & CE & EE \\
& Média (DP) & Média (DP) & Média (DP) & Média (DP) \\
\hline Estro & $5,5(1,21)$ & $5,1(1,44)$ & $5,9(1,28)$ & $5,6(1,43)$ \\
PEstro & $0,68(0,89)$ & $0,67(0,65)$ & $0,69(0,69)$ & $0,66(0,57)$ \\
\hline
\end{tabular}

NOTA: PEstro = eventos de proestro para estro

\subsubsection{Morfometria ovariana}

Uma redução significativa de folículos primordiais foi observada nos animais expostos ao diesel durante o período de vida intra-uterina (grupo EC) $(p=0,035)$ e durante o período pós-natal (grupo CE) $(p=0,015)$, bem como nos animais que foram expostos nas duas fases (grupo $E E)(p=0,004)$ (Figura 11). Foi possível observar também, uma redução significativa de folículos primários, entretanto, somente quando houve exposição ao diesel na fase pré-natal (grupo EC) $(p=0,04)$ como ilustrado na figura 12. 


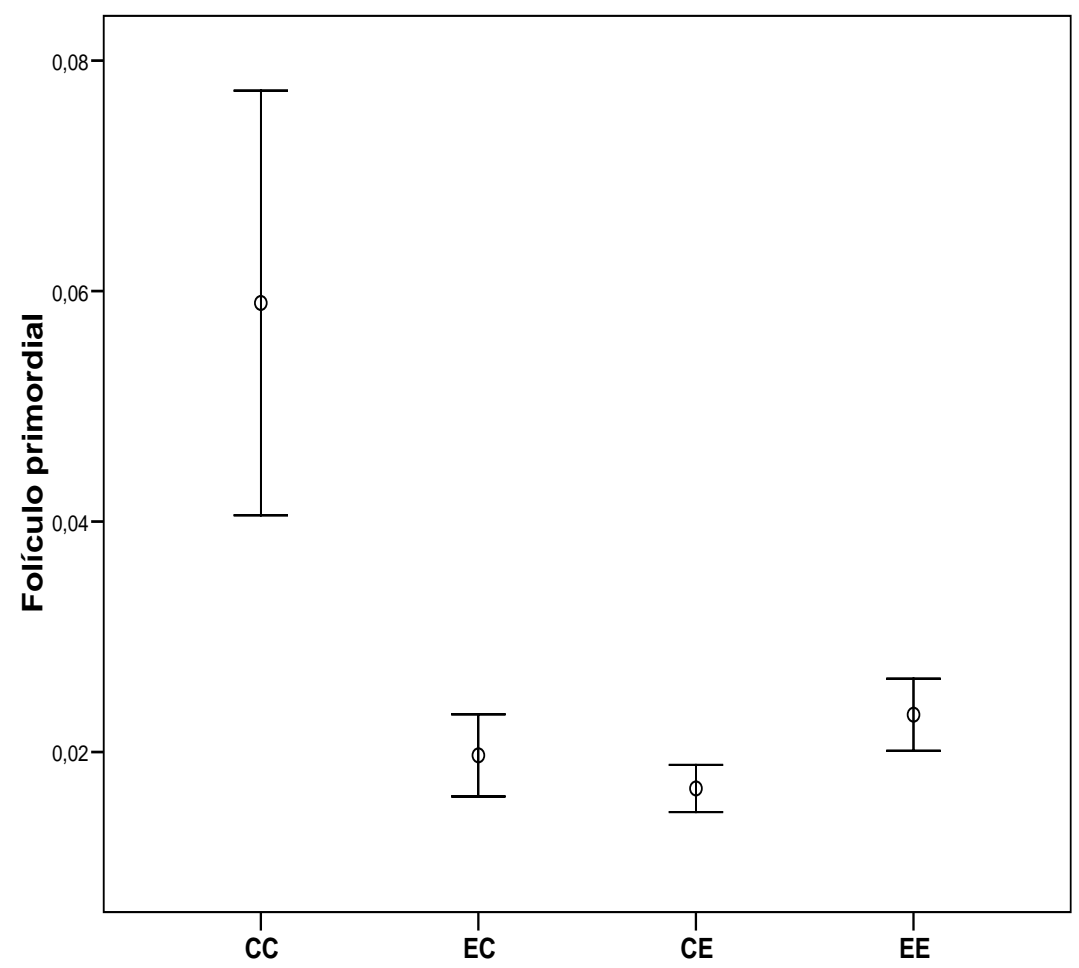

Figura 11. Representação gráfica da fração de área ocupada por folículos primordiais em todos os grupos. O círculo central representa a média e as barras verticais o erro padrão

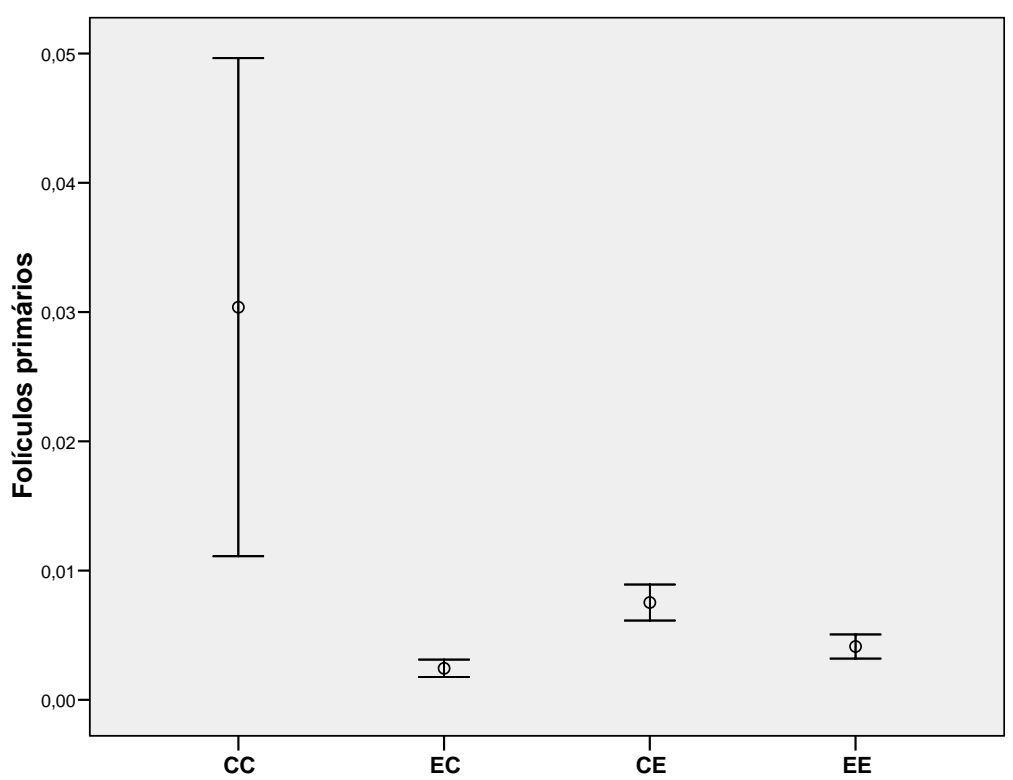

Figura12. Representação gráfica da fração de área ocupada por folículos primários em todos os grupos. O círculo central representa a média e as barras verticais o erro padrão 
Uma redução da fração de área ocupada por folículos secundários foi observada com diferença significativa limítrofe após as exposições ao diesel durante a gestação $(p=0,05)$ e no período pós-natal $(p=0,06)$. Não foram detectadas diferenças significativas na fração de área das outras estruturas avaliadas.

A tabela 9 demonstra a estatística descritiva da fração de área ocupada pelos diferentes folículos ovarianos, por corpos lúteos e de estroma ovariano presentes nos quatro grupos (Tabela 9).

Tabela 9. Estatística descritiva da fração de área (\%) ocupada por folículos, corpos lúteos e estroma ovariano para os quarto grupos de estudo (exposição intra-uterina e pós-natal)

\begin{tabular}{lccll}
\hline Parâmetros & $\begin{array}{c}\text { CC }(n=7) \\
\text { Média (DP) }\end{array}$ & $\begin{array}{c}\text { EC }(n=9) \\
\text { Média (DP) }\end{array}$ & $\begin{array}{c}\text { CE }(n=10) \\
\text { Média (DP) }\end{array}$ & $\begin{array}{c}\text { EE }(n=11) \\
\text { Média (DP) }\end{array}$ \\
\hline Primordial & $0,059(0,048)^{\star \star}$ & $0,019(0,010)$ & $0,016(0,006)$ & $0,023(0,010)$ \\
Primário & $0,030(0,050)^{\star}$ & $0,002(0,002)$ & $0,007(0,004)^{\star}$ & $0,004(0,003)^{\star}$ \\
Secundário & $0,616(0,874)$ & $0,157(0,088)$ & $0,169(0,056)$ & $0,112(0,070)$ \\
Graaf & $0,051(0,085)$ & $0,023(0,033)$ & $0,046(0,062)$ & $0,032(0,037)$ \\
C Lúteo & $1,955(2,835)$ & $0,480(0,183)$ & $0,521(0,084)$ & $0,610(0,233)$ \\
Estroma & $0,906(1,564)$ & $0,308(0,116)$ & $0,207(0,037)$ & $0,288(0,107)$ \\
\hline
\end{tabular}

C Lúteo= corpo lúteo

** diferença significativa em relação aos outros grupos

* diferença significativa em relação ao grupo EC 


\subsubsection{Morfometria uterina}

A tabela 10 apresenta a estatística descritiva da fração de área ocupada pelas estruturas uterinas avaliadas. Não foi encontrada diferença significativa em nenhum dos parâmetros uterinos analisados em nenhum dos grupos (Tabela 10).

Tabela 10. Valores descritivos da fração de área (\%) dos parâmetros uterinos analisados (epitélio superficial endometrial, glândulas endometriais e estroma endometrial) dos quatro grupos analisados

\begin{tabular}{lrccl}
\hline Parâmetros & $\begin{array}{r}\text { CC }(n=7) \\
\text { Média (DP) }\end{array}$ & $\begin{array}{c}\text { EC }(n=9) \\
\text { Média (DP) }\end{array}$ & $\begin{array}{c}\text { CE }(n=10) \\
\text { Média (DP) }\end{array}$ & $\begin{array}{c}\text { EE }(n=11) \\
\text { Média (DP) }\end{array}$ \\
\hline Epitélio & $0,111(0,032)$ & $0,146(0,042)$ & $0,138(0,050)$ & $0,128(0,037)$ \\
Glândulas & $0,055(0,030)$ & $0,063(0,020)$ & $0,055(0,028)$ & $0,047(0,039)$ \\
Estroma & $0,374(0,079)$ & $0,365(0,090)$ & $0,370(0,044)$ & $0,387(0,110)$ \\
\hline
\end{tabular}


5 Discussão 
Neste estudo foi possível demonstrar que a exposição à exaustão do diesel compromete o potencial reprodutivo de camundongos, diminuindo sua reserva ovariana. Os resultados mostram que camundongos expostos à combustão do diesel, especificamente durante a vida intra-uterina, apresentam reserva ovariana diminuída evidenciada por uma redução significativa de folículos primordiais e primários quando da sua maturidade sexual ou início de vida reprodutiva. Também foi observado que a exposição ao combustível apenas no período pós-natal, ou nos dois períodos somados, altera a reserva ovariana através da redução do número de folículos primordiais. Em outras palavras, os folículos primordiais são sensíveis aos efeitos deletérios da exaustão do diesel em qualquer fase em que forem expostos e os folículos primários são afetados apenas quando há exposição durante a vida intra-uterina.

Os níveis de $\mathrm{MP}_{2.5}$ aos quais ao animais foram expostos neste experimento ficaram muito próximos do objetivo inicial de simular uma exposição crônica, a uma dose de combustão de diesel que correspondesse a uma exposição constante à concentração média diária limite recomendada pela Organização Mundial da Saúde (Quadro 4) e dentro dos limites nacionais estabelecidos pela CONAMA. Todos os grupos expostos ao diesel (intra-uterino e pós-natal) mostraram níveis significativamente diferentes dos grupos controles. 
Quadro 4. Diretrizes da Qualidade de $\operatorname{Ar}$ e Metas Provisórias para Material Particulado: média diária (24horas de exposição)

\begin{tabular}{|c|c|c|c|}
\hline $\begin{array}{l}\text { Nível médio diário } \\
\text { (exposição 24hs)* }\end{array}$ & $\begin{array}{c}\mathrm{MP}_{10} \\
\left(\mu \mathrm{g} / \mathrm{m}^{3}\right)\end{array}$ & $\begin{array}{c}\mathrm{MP}_{2.5} \\
\left(\mu \mathrm{g} / \mathrm{m}^{3}\right)\end{array}$ & Referencial \\
\hline $\begin{array}{c}\text { OMS-meta provisória } \\
\text { Nível } 1\end{array}$ & 150 & 75 & $\begin{array}{l}\text { Baseado em coeficientes de risco de } \\
\text { estudos multicêntricos e metanálises. } \\
\text { Risco } 5 \% \text { acima da diretriz de } \\
\text { qualidade de ar da OMS para } \\
\text { mortalidade a curto prazo }\end{array}$ \\
\hline $\begin{array}{l}\text { OMS-meta provisória } \\
\text { Nível } 2\end{array}$ & 100 & 50 & $\begin{array}{l}\text { Baseado em coeficientes de risco de } \\
\text { estudos multicêntricos e metanálises. } \\
\text { Risco } 2,5 \% \text { acima da diretriz de } \\
\text { qualidade de ar da OMS para } \\
\text { mortalidade a curto prazo }\end{array}$ \\
\hline $\begin{array}{c}\text { OMS-meta provisória } \\
\text { Nível } 3\end{array}$ & 75 & 37,5 & $\begin{array}{l}\text { Risco } 1,2 \% \text { acima da diretriz de } \\
\text { qualidade de ar da OMS para } \\
\text { mortalidade a curto prazo }\end{array}$ \\
\hline $\begin{array}{c}\text { OMS } \\
\text { Diretrizes de } \\
\text { Qualidade de Ar* }\end{array}$ & 50 & 25 & $\begin{array}{l}\text { Baseado na relação entre nível } \\
\text { diário e anual de material } \\
\text { particulado }\end{array}$ \\
\hline
\end{tabular}

*NOTA: A média diária refere-se ao percentil 99 da distribuição de valores de exposição ao longo do dia, em 3 dias no ano.

A Organização Mundial da Saúde estabeleceu diretrizes de qualidade de ar para a média anual de exposição ao $\mathrm{MP}_{2.5}$ em exposições crônicas que corresponde a concentração de $10 \mu \mathrm{g} / \mathrm{m}^{3}$ (WHO, 2005) (Quadro 5). Esta concentração está baseada no menor nível de exposição a partir do qual a mortalidade cardiopulmonar e o câncer de pulmão aumentam em 95\% o intervalo de confiança, segundo no estudo da sociedade americana de câncer (Pope, 2000). 
Além das diretrizes gerais determinadas pela OMS para exposições diárias (agudas) e anuais (crônicas), três metas provisórias chamadas de ínterim targets (IT) foram estabelecidas com o intuito de auxiliar os países no processo de aferição ao longo do tempo até chegar ao nível ideal. No caso de exposições crônicas, a meta provisória nível 1 (IT-1), que representa a média anual de $35 \mu \mathrm{g} / \mathrm{m}^{3}$, está associada às maiores concentrações observadas em estudos mostrando efeitos deletérios para a saúde a longo prazo e poderá também refletir níveis maiores passados, porém não aferidos, que poderiam ser responsáveis pelos efeitos observados. Este nível está associado a uma mortalidade a longo prazo 15\% maior do que o nível determinado pelas diretrizes ideais de qualidade de ar. O nível 2 (25 $\mu \mathrm{g} / \mathrm{m}^{3}$ ), diminui em $6 \%$ o risco de mortalidade prematura comparado ao nível 1-OMS e o nível 3, de $15 \mu \mathrm{g} / \mathrm{m}^{3}$, reduz o risco em mais 6\% comparado ao nível 2 -OMS.

Neste experimento, todos os grupos de estudo foram expostos a níveis de $\mathrm{MP}_{2.5}$ que giraram em torno do nível 2 das metas provisórias anuais da OMS (exposição crônica intra-uterina = $27.91 \mu \mathrm{g} / \mathrm{m}^{3}$; exposição crônica pós-natal = $21.48 \mu \mathrm{g} / \mathrm{m}^{3}$ ). 
Quadro 5. Diretrizes da Qualidade de Ar e Metas Provisórias para Material Particulado: média anual

\begin{tabular}{|c|c|c|c|}
\hline Nível média anual & $\begin{array}{c}\mathrm{MP}_{10} \\
\left(\boldsymbol{\mu g} / \mathbf{m}^{3}\right)\end{array}$ & $\begin{array}{c}\mathrm{MP}_{2.5} \\
\left(\boldsymbol{\mu g} / \mathbf{m}^{3}\right)\end{array}$ & Referencial \\
\hline $\begin{array}{c}\text { OMS-meta provisória } \\
\text { Nível 1 }\end{array}$ & 70 & 35 & $\begin{array}{l}\text { mortalidade a longo prazo 15\% acima } \\
\text { da diretriz de qualidade de ar da OMS }\end{array}$ \\
\hline $\begin{array}{c}\text { OMS -meta provisória } \\
\text { Nível 2 }\end{array}$ & 50 & 25 & $\begin{array}{l}\text { mortalidade reduz em média 6\%( 2- e } \\
11) \text { comparado ao nível 1-OMS }\end{array}$ \\
\hline $\begin{array}{c}\text { OMS- meta provisória } \\
\text { Nível 3 }\end{array}$ & 30 & 15 & $\begin{array}{l}\text { mortalidade reduz mais 6\% (2-11), } \\
\text { comparado ao nível 2-OMS }\end{array}$ \\
\hline $\begin{array}{c}\text { OMS } \\
\text { Diretrizes de } \\
\text { Qualidade de Ar }\end{array}$ & $\mathbf{2 0}$ & $\mathbf{1 0}$ & $\begin{array}{l}\text { menores níveis para mortalidade } \\
\text { cardiopulmonar e câncer de pulmão }\end{array}$ \\
\hline
\end{tabular}

A CONAMA (1990) descreve limites de segurança para exposição a partículas inaláveis em resolução $n^{\circ} 3$ de 28/06/90. Esta resolução estabeleceu que Padrões Primários de Qualidade de Ar são as concentrações de poluentes que, caso ultrapassadas, poderiam afetar a saúde da população, e Padrões Secundários de Qualidade de Ar são as concentrações de poluentes abaixo das quais se prevê o mínimo efeito adverso sobre o bemestar da população, assim como o mínimo dano à fauna, à flora, aos materiais e ao meio ambiente em geral . O limite de exposição diário estabelecido como padrão primário e secundário para MP fino foi de $150 \mu \mathrm{g} / \mathrm{m}^{3}$, não excedendo em mais de 1 vez ao ano; o limite de exposição anual, estabelecido também como primário e secundário, foi de $50 \mu \mathrm{g} / \mathrm{m}^{3}$. 
Foi possível constatar que mesmo o grupo exposto ao diesel, que apresentou maior concentração de MP, apresentou concentração aproximadamente $50 \%$ menor do que o permitido segundo os parâmetros nacionais.

Todos os grupos controles (expostos ao ar filtrado) tiveram níveis de $\mathrm{MP}_{2.5}$ muito abaixo dos limites diário e anual estabelecidos pela OMS e pela CONAMA.

O número de oócitos presentes em mamíferos após o nascimento é determinado precocemente na vida intra-uterina. $O$ tamanho da reserva ovariana depende de diversos fatores, como o número de células germinativas primordiais que migram para a crista gonadal, a atividade mitótica destas células diplóides e o desgaste das oogônias e oócitos, particularmente quando estas passam pelos estágios da meiose. As células germinativas primordiais chegam à crista gonadal em torno do décimo terceiro dia após a fecundação no camundongo (Tam e Snow, 1981) e no trigésimo quinto dia em humanos (Witschi, 1948). Durante o período de migração das células germinativas primordiais até a crista gonadal, a atividade mitótica é intensa. Em camundongos, o número de células germinativas primordiais foi estimado em 100 no oitavo dia embrionário, quando inicia a migração, ao passo que no décimo terceiro dia, a estimativa passou a ser de 11000 por gônada (Tam e Snow, 1981). Em mamíferos, o tempo estimado para que a mitose ocorra, entre a chegada das primeiras oogônias e as últimas à crista gonadal, é de apenas 2 semanas (Witschi, 1948; van Wagenen e Simpson, 1965). Portanto, ao redor do dia 50 de vida embrionária humana, a reserva ovariana está definida. 
Após o início da meiose, a proliferação mitótica já não é mais possível e os oócitos são envolvidos em uma camada de células passando a ser chamados de folículos, as unidades reprodutivas do ovário (Biskov e Nielsen, 2003). Desta forma, um número finito de oócitos fica estabelecido, e deste momento em diante, a reserva ovariana ou folicular apenas decresce através de mecanismos degenerativos ou evoluindo até o estágio da ovulação, até o esgotamento desta reserva na menopausa (Gougeon, 1996).

Qualquer etapa de desenvolvimento descrito acima poderia ter sido afetada pela exposição à combustão do diesel durante a vida intra-uterina. A meiose, em especial a prófase da meiose, é descrita como uma das etapas mais críticas onde $30 \%$ a $50 \%$ dos oócitos não sobrevive ao processo natural e sofre apoptose (camundongos: Borum, 1961; humanos: Baker, 1963). Em contraste com os humanos, em que os folículos são formados durante a vida fetal, nos camundongos, os primeiros folículos são formados próximo ao dia do nascimento (Biskov, 1986); portanto os ovários foram analisados, neste estudo, na fase adulta quando os animais atingiram sua maturidade sexual.

O fato de os ovários dos animais neste estudo não terem sido analisados logo após o nascimento, não permite concluir que os animais nascem com a reserva ovariana diminuída. Para os grupos expostos na fase intra-uterina, a perda poderá ter ocorrido tanto intra-útero, como o processo poderá ter sido desencadeado intra-útero e transcorrido até o momento da maturidade sexual. Para os grupos expostos no período pós-natal, foi considerada como hipótese, a ativação ou aceleração de mecanismos degenerativos, como a apoptose. 
Interessantemente, apesar do tempo de exposição ao diesel no período pós-natal ter sido três vezes mais longo em extensão de dias, comparado à exposição pré-natal, os efeitos sobre a reserva ovariana foram mais significativos nos camundongos expostos durante a vida intra-uterina. Este achado vem de encontro à hipótese de que acontecimentos na fase embrionária e fetal podem repercutir na vida adulta.

Diversos estudos, desde o final da década de 80 vêm demonstrando que o ambiente intra-uterino, quando alterado por algum fator externo, juntamente com a plasticidade do desenvolvimento fetal, adaptando-se ao ambiente adverso, pode modificar permanentemente a saúde do adulto. O responsável por criar esta hipótese foi o professor David Barker (Barker et al., 1989). Dentro desta linha de estudo chamada de epigenômica, que corresponde a alterações hereditárias na expressão gênica que ocorrem sem a mudança no sequenciamento do DNA (Bollati e Bacarelli, 2010), um dos modelos mais citados é a comprovação da relação de baixo peso ao nascer com o desenvolvimento de doença vascular coronariana, diabetes tipo 2, hipercolesterolemia e hipertensão no adulto (Damaceno-Rodrigues et al., 2009; Kanaka-Gantenbein, 2010; Luo et al., 2006; Morley, 2006). Nesta relação, foi observado que os fatores nutricionais da mãe ao longo de sua própria vida fetal até a vida adulta e durante a gestação, influenciam no crescimento de seu feto e, por conseguinte, predispõem ao desenvolvimento da síndrome metabólica na idade adulta (Skinner et al., 2010).

Os mecanismos epigenéticos envolvem, no geral, alterações na metilação do DNA (Holiday e Pugh, 1975), modificações de histonas (Turner, 
1998) e formação de RNA não-codificante (Pokholok et al., 2005) em um período absolutamente vulnerável onde as exposições podem ocasionar seus maiores efeitos adversos, reprogramando a fisiologia e ocasionando a doença futura (Odom e Taylor, 2010). Os estudos nesta área seguem diversas etapas como comprovar que um determinado componente químico é capaz de interferir na expressão gênica, identificar o seu marcador, correlacionar o marcador com o período de exposição e comprovar que aquela alteração epigenética é fator de risco para o desenvolvimento de determinada doença (Baccarelli e Bollati, 2009) (Figura 13).

\section{EXPOSIÇÃO}

INFLAMAÇÃO, ESTRESSE OXIDATIVO,

DISFUNÇA̧O HORMONAL, INFLUÊNCIẢ SOBRE

ATIVIDADES ENZIMÁTICÁS

METILAÇÃO DE DNA, MODIFICAÇÕES DE

HISTONAS , FORMAÇÃO DE RNA NÃO-

CODIFICANTE

EXPRESSÃO GÊNICA; CONDENSAÇÃO DA

CROMATINA

\section{RISCO PARA DOENÇA}

Figura 13. Múltiplas alterações biológicas causadas por exposições a agentes químicos que desencadeiam mecanismos epigenéticos, como a metilação de DNA, modificação de histonas e formação de RNA não-codificante levando a alterações de expressão gênica e condensação de cromatina, influenciando os riscos para doenças. 
Os poluentes ambientais, em especial componentes da poluição veicular, são conhecidos por ocasionar alterações epigenéticas. Possíveis mecanismos de indução de morte celular por hidrocarbonetos policíclicos aromáticos, componentes da exaustão do diesel, como dano direto à estrutura do DNA ou a ativação do receptor do aril hidrocarboneto (Ahr), que conseqüentemente, altera a expressão gênica das células foram descritos na literatura por Denissenko et al., em 1996, e Juriscova et al, em 2007. Os hidrocarbonetos policíclicos aromáticos, compostos presentes no material particulado e na fração gasosa do diesel, foram relacionados à asma na infância, sendo possível detectar o seu marcador em células do tecido fetal quando a mãe foi exposta a inalação de doses de $2,41 \mathrm{ng} / \mathrm{m}^{3}$ (Perera et al., 2009).

O benzeno é um composto aromático da porção orgânica volátil da queima do diesel presente no carbono negro e no $\mathrm{MP}_{2.5}$. Estudos demonstraram que a exposição de indivíduos saudáveis ao benzeno presente na poluição veicular é capaz de provocar aberrações no processo de metilação do DNA. (Bollati e Bacarelli, 2007; Nawrot e Adcock, 2009). Marcadores para esta metilação provocada pelo benzeno estão vinculados à patologia da leucemia mielóide aguda (Lubbert et al., 1992).

Outro exemplo de fenômeno epigenético é a ativação dos sistemas reprodutores feminino e masculino, em momento inoportuno durante o seu desenvolvimento intra-uterino, por substâncias que possuem efeitos que mimetizam hormônios, os desreguladores endócrinos. Diversos estudos demonstram claramente estes efeitos: a exposição pré-natal ao 
dietilestilbestrol (DES) é capaz de causar anomalias anatômicas em homens e mulheres, principalmente no aparelho reprodutor, além de aumentar a incidência de tumores como o adenocarcinoma de vagina em jovens cujas mães foram expostas durante a gestação (Goodman et al., 2011); a exposição ao pesticida metoxicloro, que possui efeitos estrogênicos, no período embrionário na fase de diferenciação sexual, afeta a composição celular do embrião e o número de células germinativas no testículo (Cupp et al., 2003); uma exposição transitória ao vinclozolin, um fungicida antagonista do receptor de androgênio usado em vinhedos, aumenta o índice apoptótico de células germinativas no testículo de animais púberes e adultos (Uzumcu et al., 2004); um componente do plástico chamado bisphenol A, que possui efeitos estrogênicos, é conhecido por causar inúmeras patologias incluindo baixo peso ao nascer (Miao et al., 2011), menor número de nascidos vivos em modelos experimentais (Cabaton et al, 2011), câncer de próstata (Ho et al., 2006) e câncer de mama no adulto (Weber e Keri, 2011).

A frequência em que fatores ambientais podem provocar alterações no epigenoma de tecidos somáticos é muito maior do que alterações nas células germinativas devido ao tempo limitado em que estas são vulneráveis à reprogramação. Quando o período de migração das células germinativas à crista gonadal é afetado ou quando o processo de diferenciação sexual a nível celular é afetado, uma linhagem de células germinativas estará permanentemente reprogramada, possibilitando a ocorrência de um fenômeno chamado de epigenética transgeracional, transmitindo um fenótipo modificado a futuras gerações (Jirtle e Skinner, 2007; Anway et al., 2005). 
Para que um fenômeno seja considerado transgeracional, é necessária a exclusão de exposição direta ao componente agressor e a transmissão do fenótipo diferenciado deverá estar presente, no mínimo, nas três gerações subseqüentes (Skinner et al., 2010). Em um estudo envolvendo camundongos expostos ao ar ambiente em uma fábrica de aço, Yauk et al. (2008), mostraram que o DNA dos espermatozóides apresentava-se hipermetilado comparado aos animais controles, e que esta alteração persistiu após a remoção da exposição ambiental. Este achado alerta para a possibilidade de transmissão das modificações às próximas gerações.

Em analogia com o nosso estudo, Watanabe, no Japão, realizou um experimento equivalente, expondo ratos durante a vida intra-uterina às emissões do diesel e analisando a espermatogênese na fase adulta. Ainda, separou os animais em 4 grupos, um exposto a altas concentrações de diesel, outro a baixas concentrações, outro filtrado para passagem apenas da fração gasosa do diesel e outro grupo exposto a ar totalmente filtrado. $\mathrm{O}$ autor constatou que a produção diária de espermatozóides, de espermátides e de células de Sertoli nos grupos expostos ao diesel (altas e baixas concentrações) estava diminuída, comparado ao grupo controle, na idade adulta dos animais. A razão espermátide/ célula de Sertoli e os níveis de FSH nos grupos expostos estavam significativamente aumentados. Este estudo demonstrou que a exposição intra-uterina ao diesel leva a uma deficiência de células de Sertoli no animal na idade adulta. O fato de não ter havido diferença entre os grupos expostos à composição total das emissões e o grupo exposto apenas à fração gasosa, sugere que os responsáveis por estes efeitos estão nesta fração do diesel (Watanabe, 2005). 
Os resultados observados na reserva ovariana após a exposição ao diesel apontam claramente para a possibilidade de um fenômeno epigenético, além da possibilidade de estar presente um efeito transgeracional. A continuidade da pesquisa para identificar alterações da expressão gênica, seus marcadores e os mecanismos desencadeados que levaram aos achados deste estudo será de grande importância para elucidar esta questão. Uma avaliação de maior número de gerações permitirá concluir se o período afetado foi o da oogênese, além de esclarecer se trata-se de um fenômeno transgeracional. Ainda assim, este estudo é o primeiro a levantar a possibilidade de efeitos epigenéticos envolvendo um poluente veicular presente no cotidiano de diversas áreas metropolitanas e o potencial reprodutivo feminino através da análise de sua reserva ovariana.

Além dos achados no grupo de exposição apenas intra-uterina, de forma clara, foi observada uma menor reserva ovariana dos camundongos adultos quando estes foram expostos ao diesel somente no período pósnatal, aumentando também o seu risco de menopausa precoce.

Quando levamos em conta a exposição ao longo da vida do ser humano após o nascimento, muitos agentes externos estão relacionados à menopausa precoce ou a infertilidade transitória. Os mais conhecidos são os quimioterápicos e a radioterapia utilizada em tratamentos oncológicos (Basille et al., 2010). Dentre os componentes ambientais, a exposição à fumaça do tabaco é um dos únicos poluentes relacionados a uma redução da idade da menopausa (Ottinger, 2010). Fleming et al. (2008), demonstraram que o uso de cigarro e o fumo passivo em ambientes de trabalho estão associados a 
uma maior chance de redução da idade em que se atingiria a menopausa, sugerindo que o controle de exposições passivas e secundárias à fumaça do cigarro no ambiente de trabalho poderia diminuir a morbidade e a mortalidade relacionada à menopausa precoce. Da mesma forma, Ottinger, em 2010 correlacionou a idade da perimenopausa com o tabagismo.

Até o presente, apenas um estudo relacionando efeitos deletérios da poluição ambiental sobre a contagem folicular foi publicado. Veras, et al. (2009), em um estudo multigeracional, encontrou uma menor quantidade de folículos antrais na geração parental de camundongos expostos à poluição atmosférica, porém não foram encontradas alterações ovarianas na geração de filhotes. Uma das maiores diferenças desse estudo com o presente estudo, é que ele foi conduzido com a poluição atmosférica e não com um componente específico da poluição como a combustão do combustível diesel. Além disso, os resultados da análise ovariana indicaram uma redução de folículos antrais, que são folículos secundários. Os folículos secundários são folículos que podem evoluir até a ovulação ou atresiar. Portanto, o estudo revela uma suscetibilidade em estágios mais avançadas do desenvolvimento folicular, mas não o comprometimento da reserva ovariana, que é determinada precocemente na vida embrionária, com o potencial para afetar as próximas gerações.

Da mesma forma em que a exposição ao tabaco corrobora para a redução da idade da menopausa, estes achados sugerem que há uma estimulação do processo fisiológico de atresia folicular ou até ativação de 
mecanismos de apoptose como parte do processo fisiopatológico causado pela exposição a poluentes durante a vida pós-natal.

Considerando que há dois períodos-alvo onde, se interferidos, podem levar a insuficiência ovariana prematura ou menopausa precoce, a interferência na oogênese e a destruição de oócitos, este estudo levanta a hipótese de que ambos possam ter sido afetados pela exposição ao combustível diesel devido a demonstração dos mesmos resultados no grupo exposto apenas intra-útero e no grupo exposto apenas na vida pós-natal. Permanece a questão se o grupo que foi exposto apenas na vida intrauterina transmitiria este fenótipo a futuras gerações.

A metodologia para contagem folicular ovariana é controversa na literatura, pois diversas técnicas são descritas, cada um apresentando prós e contras em termos de eficiência. A classificação em folículos primordiais, primários, secundários e terciários está baseada em características biológicas, porém é uma análise subjetiva. Além disto, usualmente o folículo tem um diâmetro maior que as secções histológicas padronizadas e podem constar em secções subseqüentes. Neste experimento, procurou-se respeitar os fatores mais importantes descritos como determinantes na contagem folicular: a mesma metodologia de contagem foi aplicada para todos os grupos de estudo, o mesmo examinador fez a leitura histológica e a análise foi cega para este examinador (Tilly, 2003).

Neste estudo, esperava-se encontrar alterações morfológicas uterinas, especialmente endometriais, pelos conhecidos efeitos estrogênicos dos componentes resultantes da queima de combustíveis fósseis (Jingxian 
et al., 2003). No que tange ao combustível diesel, diversos componentes foram isolados do MP como o 3-metil-4-nitrofenol (4-nitr0-m-cresol; PNMC) e o 4-nitro-3-fenilfenol (PNMPP). Seus efeitos estrogênicos foram identificados através dos achados de um maior peso do útero e uma maior contratilidade in vivo e in vitro em ratos tratados com tais componentes (Furata et al., 2004). Ainda, em estudos subseqüentes, foi identificada atividade estrogênica de PNMC e PNMPP através de achados como proliferação celular do epitélio endometrial em análises imunohistoquímicas (Furata et al., 2005). Li et al., em 2006, demonstrou efeitos estrogênicos e antiandrogênicos in vivo em ratos do 4-nitrofenol, também através de aumento do peso uterino e diminuição dos pesos das vesículas seminais, da próstata e dos músculos do bulbo cavernoso e da glande. Por outro lado, outro estudo sobre os efeitos das emissões do diesel em camundongos mostrou uma redução significativa no peso dos úteros no período de estro das fêmeas expostas diariamente a altas doses ao longo de quatro meses (Tsukue et al., 2002). Uma investigação qualitativa do útero para detectar possíveis alterações resultantes da exposição à combustão do diesel poderia revelar mecanismos não detectados na análise quantitativa.

Embora Veras et al. (2009) tenham encontrado alterações no ciclo estral de camundongos expostos à poluição atmosférica, demonstrado através de estro prolongado e, consequentemente, menor número de ciclos no grupo exposto, o presente estudo não evidenciou alterações de ciclicidade. Uma possível explicação para isto poderia ser a existência de câmara única para todos os grupos de exposição. Apesar de o gerador 
permanecer em funcionamento por pelo menos 25 minutos fazendo com que ar filtrado passasse por todo o circuito para limpar o sistema antes da exposição dos grupos, ainda foi possível detectar uma quantidade pequena de MP nos filtros dos grupos controles. A dose de MP detectável nos grupos controles foi aproximadamente 10 vezes menor que nos grupos expostos, no entanto, poderá ter sido o suficiente para que não fossem detectadas diferenças significativas entre os grupos para este parâmetro.

Se assumirmos extrapolar os resultados deste estudo para humanos, veremos que estes estão alinhados aos estudos epidemiológicos que demonstram a diminuição da fertilidade masculina ao longo das últimas décadas (Povey e Stocks, 2010) e também aos estudos experimentais que geram modelos explicativos para os primeiros (Watanabe, 2005) citados anteriormente.

Fêmeas de mamíferos, como camundongos e humanos, já nascem com seu potencial reprodutivo determinado pelo tamanho da sua reserva ovariana ou pool de oócitos. Foi demonstrado que a exposição crônica à combustão do diesel afeta negativamente o futuro potencial reprodutivo das fêmeas, aumentando a chance de falência ovariana prematura. Novas investigações são necessárias para elucidar os possíveis mecanismos envolvidos nos resultados deste estudo.

Os fatores ambientais que causam infertilidade decorrente da industrialização crescente somam-se à mudança de perfil das taxas de fecundidade mundiais por motivação comportamental. 
Países desenvolvidos apresentam baixas taxas de natalidade devido ao adiamento da maternidade por adesão das mulheres à vida acadêmica ou à competitividade no trabalho (Collins et al., 2010). As conseqüências disto são um grande ônus aos sistemas de saúde com o crescente número de idosos, além de falta de mão-de-obra jovem e perspectiva de projetos inovadores nas áreas científicas e tecnológicas. O Brasil, país em desenvolvimento, já apresentou taxas de fecundidade muito elevadas, de 6,3 filhos por casal na década de 60 , representando uma ameaça à população para sobrevivência em condições dignas. No ano 2000, a taxa de fecundidade do país passou para 2,3 por casal (IBGE, 2002), demonstrando um crescimento populacional em ritmo muito mais lento. As causas deste decréscimo no país são semelhantes aos dos países desenvolvidos, com o engajamento das mulheres em carreiras profissionais, porém destaca-se a melhora das condições sócio-econômicas e culturais, possibilitando acesso a programas de controle de natalidade e a contraceptivos. Caso a diminuição da taxa de fecundidade do Brasil, mais o desejo de preterir a maternidade, aliem-se a diminuição da fertilidade feminina causada por fatores ambientais, o país estará a caminho dos mesmos dilemas já vividos nos países europeus.

O surgimento de estudos epidemiológicos com o intuito de interligar a poluição ambiental com a idade da menopausa em diferentes populações, tal qual estudos que associam o tabagismo à menopausa, poderia contribuir de maneira significativa para esta linha de pesquisa e para mudanças nas políticas ambientais. 
Profissionais da saúde, em especial, profissionais que tratam e orientam mulheres em idade reprodutiva, estão em uma posição privilegiada para fornecer informações que possam proteger contra possíveis alterações epigenéticas e assim prevenir seu impacto no feto em desenvolvimento e consequentemente sua saúde futura. 
6 Conclusão 
Este estudo permitiu concluir que a exposição crônica, intra-uterina ou pós-natal, às emissões do combustível diesel leva a redução da reserva folicular ovariana de camundongos na fase adulta.

$\checkmark$ A exposição crônica ao diesel, apenas no período intra-uterino, é capaz de reduzir a proporção de folículos primordiais e primários no camundongo adulto.

$\checkmark$ A exposição crônica ao diesel, apenas no período pós-natal, é capaz de reduzir a proporção de folículos primordiais no camundongo adulto.

$\checkmark$ A exposição associada nos período intra-uterino e pós-natal reduziu a proporção de folículos primordias do camundongo adulto.

$\checkmark$ A exposição crônica ao diesel, no período intra-uterino ou pósnatal, ou ambos, não alterou morfologicamente o endométrio de camundongos adultos.

Não foram observadas alterações significativas na ciclicidade estral causadas pela exposição ao combustível diesel em nenhum dos períodos.

$\checkmark$ O sistema de exposição dos animais foi eficiente para manter diferenças significativas de material de emissões do diesel entre os grupos controle e expostos. 
Os resultados ressaltam a importância de revisões mais freqüentes das políticas nacionais e internacionais de qualidade de ar ambiental e suas repercussões na saúde humana, visto que há evidências de que os limites atuais recomendados pelos órgãos reguladores vêm sendo prejudiciais, afetando a saúde não somente de forma direta, mas de futuras gerações. 
7 Referências 
Abdul-Khalek I S, Kittelson D, Graskow B, Wei Q, Bear F. Diesel Exhaust Particle Size: Measurement Issues and Trends. SAE Technical Paper Series 1998; 980525: 13.

ANP. Agência Nacional do Petróleo, Gás Natural e Biocombustíveis.Resolução CNPE n 6, de 16.09.2009 - DOU 26.10.2009

ANP. Agência Nacional do Petróleo, Gás Natural e Biocombustíveis. Resolução No 13, de 30.4.2008 - DOU 2.5.2008.

Anway MD, Cupp AS, Uzumcu M, Skinner MK. Epigenetic transgenerational actions of endocrine disruptors and male fertility. Science 2005 ;308(5727):1466-9. Erratum in: Science 2010;328(5979):690.

Arbak P, Balbay O, Annakkaya AN, Bilgin C, Ozsahin SL. Annual changes in forced expiratory flows in toll collectors: results from a four years observation. Ind Health 2009; 47(2): 160-5.

Baccarelli A, Bollati V. Epigenetics and environmental chemicals. Curr Opin Pediatr. 2009 April; 21(2): 243-251. Curr Opin Pediatr 2009; 21(2): 243-251.

Baker TG. A quantitative and cytological study of germ cells in human ovaries. Philos Tran R Soc Lond B 1963; 158: 417-33.

Barker DJP, Osmond C, Winter PDW, Margetts B, Simmonds SJ. Weight in infancy and death from ischemic heart disease. Lancet 1989; 577-80. 
Basille C, Torre A, Grynberg M, Gallot V, Frydman R, Fanchin R. Statement: cancer treatments and ovarian reserve. J Gynecol Obstet Biol Reprod (Paris), 2010; 39(6):433-43.

Biskov AG. Differentiation of mammalian embryonic gonad. Physiol Rev 1986; 66:71-117.

Biskov AG and Nielsen M, Ontogeny of the mammalian ovary. In: Trounson AO, Gosden RG. Biology and Pathology of the Oocyte, Role in fertility and reproductive medicine, 2003. Cambridge University Press, Cambridge, UK, pp 13-25.

Black JA, Birge WJ, Westerman AG, Francis PC. Comparative Aquatic Toxicology of Aromatic Hydrocarbons. Fund App1 Toxicol 1983;3:353-358.

Boldo E, Linares C, Lumbreras J, Borge R, Narros A, García-Pérez J, Fernández-Navarro P, Pérez-Gómez $B$, Aragonés N, Ramis R, Pollán M, Moreno T, Karanasiou A, López-Abente G. Health impact assessment of a reduction in ambient PM(2.5) levels in Spain. Environ Int. 2010; 37(2):3428.

Bollati V, Baccarelli A. Environmental epigenetics. Heredity 2010;105(1):105-12.

Bollati V, Baccarelli A, Hou L, Bonzini M, Fustinoni S, Cavallo D, Byun HM, Jiang J, Marinelli B, Pesatori AC, et al. Changes in DNA methylation patterns in subjects exposed to low-dose benzene. Cancer Res 2007;67:876-880.

Bond TC, Sun H. Can Reducing Black Carbon Emissions Counteract Global Warming? Environ Sci Technol, 2005, 39 (16):5921-5926. 
Borum K, Oogenesis in the mouse. Exp Cell Res 1961; 24: 495-507.

Brito JM, Belotti L, Toledo AC, Antonangelo L, Silva, FS, Alvim DS, Andre PA, Saldiva PHN, Rivero DHRF. Acute Cardiovascular and Inflammatory Toxicity Induced by Inhalation of Diesel and Biodiesel Exhaust Particles. Toxicological Sciences 2010; 116(1): 67-78.

Brunekreef B, Beelen R, Hoek G, Schouten L, Bausch-Goldbohm S, Fischer $P$, Armstrong B, Hughes $E$, Jerrett $M$, van den Brandt $P$. Effects of long-term exposure to traffic-related air pollution on respiratory and cardiovascular mortality in the Netherlands: the NLCS-AIR study. Res Rep Health Eff Inst 2009 (139);5-71: 73-89.

Cabaton NJ, Wadia PR, Rubin BS, Zalko D, Schaeberle CM, Askenase MH, Gadbois JL, Tharp AP, Whitt GS, Sonnenschein C, Soto AM. Perinatal exposure to environmentally relevant levels of bisphenol A decreases fertility and fecundity in CD-1 mice. Environ Health Perspect. 2011;119(4):547-52.

(Cal-EPA). California Environmental Protection Agency. Report to the California Air Resources Board on the proposed identification of diesel exhaust as a toxic air contaminant, 1998a, Appendix III, part A: Exposure assessment, April 1998, http://www,arb,ca,gov/regact/diesltac/diesltac,htm.

Calo WA, Quintana R, Catoni I, Valle Y, Alvarez JJ, Colón WM, Delgado MS, Estrella M, González AL, Kallis M, Marrero VM, Meléndez L, Miranda AI, Nieves K, Osorio L, Rodríguez JM, Torres A, Suárez E, Ortiz AP. Clinical conditions associated with environmental exposures: an epidemiologic study in two communities in Juana Díaz, Puerto Rico. P R Health Sci J 2009; 28 (2):126-34. 
CETESB. Companhia de Tecnologia de Saneamento Ambiental. Relatório de qualidade do ar no Estado de São Paulo - 2008. Cetesb, 354p., São Paulo, 2009.

Collins J, Evers JL, Leridon H, Lutz W, te Velde E, Thevenon O, Crosignani PG, Devroey P, Diedrich K, Fauser BC, Fraser L, Geraedts JP, Gianaroli L, Glasier A, Sunde A, Tarlatzis B, Van Steirteghem A, Veiga A, Collins J, Crosignani PG. Europe the continent with the lowest fertility. Hum Reprod Update 2010;16(6):590-602.

CONAMA. Conselho Nacional do Meio Ambiente. Resolução 18 de 06.05.1986. Dispõe sobre a criação do Programa de Controle da Poluição do Ar por Veículos Automotores - PROCONVE. Diário Oficial da República Federativa do Brasil, Brasília, 17.06.1986.

CONAMA. Conselho Nacional do Meio Ambiente. Resolução 03 de 28.06.1990. Estabelece padrões para a qualidade do ar. Diário Oficial da República Federativa do Brasil, Brasília, 20.08.1990.

Cupp AS, Uzumcu M, Suzuki H, Dirks K, Phillips B, Skinner MK. Effect of transient embryonic in vivo exposure to the endocrine disruptor methoxychlor on embryonic and postnatal testis development. J Androl. 2003;24(5):736-45.

Damaceno-Rodrigues NR, Veras MM, Negri EM, Zanchi ACT, Rhoden CR, Saldiva PHN, Dolhnikof M, Caldini EG. Effect of pré-and postnatal exposure to urban air pollution on myocardial lipid peroxidation levels in adult mice. Inhalation Toxicology 2009; 21 (13): 1129-1137.

Denissenko MF, Venkatachalam S, Ma YH, and Wani AA. Site-specific induction and repair of benzo[a]pyrene diol epoxide DNA damage in human $\mathrm{H}$-ras protooncogene as revealed by restriction cleavage inhibition. Mutat, Res 1996; 363:27-42. 
Di Giampaolo L, Quecchia C, Schiavone C, Cavallucci E, Renzetti A, Braga M, Di Gioacchino M. Environmental pollution and asthma. Int J Immunopathol Pharmacol 2011; 24(1 Suppl):31S-38S.

EPA. Environmental Protection Agency. A comprehensive analysis of biodiesel impacts on exhaust emissions. Estados Unidos : US EPA, 2002a. 420-P-02-001.

EPA. Environmental Protection Agency. Air pollution orientation course. Sources of Pollution in the Ambiente Air, 2010. EUA. Disponível: www.epa.gov/oar/oaqps/eog/course422/ap3.html

EPA. Environmental Protection Agency. Compendium method TO-14A : Determination of volatile organic compounds (VOCs) in ambiente air using specially prepared canisters with subsequent analysis by gas chromatography. In : Compendium of methods for the determination of toxic organic compounds in ambiente air, 1999a, $2^{\text {nd }}$ Edition.

EPA. Environmental Protection Agency. Compendium method TO-15: Determination of volatile organic compounds (VOCs) in ambiente air using specially prepared canisters with subsequent analysis by gas chromatography. In : Compendium of methods for the determination of toxic organic compounds in ambiente air, 1999b, $2^{\text {nd }}$ Edition.

Fleming LE, Levis S, Le Blanc WG, Dietz NA, Arheart KL, Wilkinson JD, Clark J, Serdar B, Davila EP, Lee DJ. Earlier Age at Menopause, Work and Tobacco Smoke Exposure. Menopause 2008; 15(6): 1103-1108.

Fowler T, Canlon B, Dolan D, Miller JM. The effect of noise trauma following training exposure in the mouse, Hear Res 1995; 88: 1-13. 
Furuta C, Li C, Taneda S, Suzuki AK, Kamata K, Watanabe G, Taya K, Immunohistological study for estrogenic activities of nitrophenols in diesel exhaust particles. Endocrine 2005; 27(1):33-6.

Furuta C, Suzuki AK, Taneda S, Kamata K, Hayashi H, Mori Y, Li C, Watanabe G, Taya K. Estrogenic Activities of Nitrophenols in Diesel Exhaust Particles. Biology of Reproduction 2004; 70: 1527-1533.

Goodman A, Schorge J, Greene MF. The long-term effects of in utero exposures--the DES story. N Engl J Med. 2011 Jun 2;364(22):2083-4.

Gougeon A. Regulation of ovarian follicular development in primates: facts and hypothesis. Endocr Rev 1996; 17:121-55.

Gouveia N, Bremner SA, Novaes HMD. Association between ambient air pollution and birth weight in São Paulo, Brasil. $J$ Epidemiol Community Health 2004; 58:11-7.

Ho SM, Tang WY, Belmonte de Frausto J, Prins GS. Developmental exposure to estradiol and bisphenol $A$ increases susceptibility to prostate carcinogenesis and epigenetically regulates phosphodiesterase type 4 variant 4. Cancer Res 2006;66:5624-5632.

Hoffmann B, Moebus S, Möhlenkamp S, Stang A, Lehmann N, Dragano N, Schmermund A, Memmesheimer M, Mann K, Erbel R, Jöckel KH. Residential exposure to traffic is associated with coronary atherosclerosis. Circulation. $2007 ; 116(5): 489-96$.

Holliday R, Pugh JE. DNA modification mechanisms and gene activity during development. Science. 1975;187:226-232. 
Holson JE, Nemec MD, Stump DG, Kaufman LE, Lindstrom L, Varsho BJ. Significance reliability and interpretation of developmental and reproductive toxicity study findings. In: Hood R (Ed), Developmental and Reproductive Toxicology: A practical approach. Taylor \& Francis, USA, 329-424.

Huang CY, Yao CJ, Wang C, Jiang JK, Chen G. Changes of semen quality in Chinese fertile men from 1985 to 2008. Zhonghua Nan Ke Xue, 2010; 16(8):684-8.

IBGE. Instituto Brasileiro de Geografia e Estatística. Censo demográfico brasileiro. Fecundidade e Mortalidade infantil, 2002.

Januário DA, Perin PM, Maluf M, Lichtenfels AJ, Nascimento Saldiva PH. Biological effects and dose-response assessment of diesel exhaust particles on in vitro early embryo development in mice. Toxicol Sci, 2010;117(1):200-8.

Jerrett M, Finkelstein MM, Brook JR, Arain MA, Kanaroglou P, Stieb DM, Gilbert NL, Verma D, Finkelstein N, Chapman KR, Sears mR. A Cohort Study of Traffic-Related Air Pollution and Mortality in Toronto, Ontario, Canada. Environmental Health Perspectives 2009; 117 (5): 772-777.

Jingxian W, Henkelmann B, Li Y, Kettrup A, Schramm KW. Presence os estrogenic activity from emissions of fossil fuel combustion as detected by a recombinant yeast bioassay. Atmos Environm 2003; 37: 3225-3235.

Jirtle RL, Skinner MK. Environmental epigenomics and disease susceptibility. Nat Rev Genet. 2007;8(4):253-62.

Juriscova A, Taniuchi A, Li H, Shang $Y$, Antenos $M$, Detmar J, Xu J, Matikainen T, Hernandez AB, Nunez G, Casper RF. Maternal exposure to polycyclic aromatic hydrocarbons diminishes murine ovarian reserve via 
induction of Harakiri. The Journal of Clinical Investigation, 2007; 117(12):3971-8.

Kanaka-Gantenbein C. Fetal origins of adult diabetes. Ann N Y Acad Sci. 2010;1205:99-105.

Lanças T, Kasahara DI, Prado CM, Tibério IF, Martins MA, Dolhnikoff M. Comparison of early and late responses to antigen of sensitized guinea pig parenchymal lung strips. J Appl Physiol 2006; 100(5):1610-6.

La Rovere EL, Mendes FE, Szwarcfiter L, Mattos LBR, Szwarc A. Avaliação do PROCONVE, Programa de controle da poluição do ar por veículos automotores. $2007, \quad$ 1-116 p. Disponível: http://146.164.33.61/termo/Motores/material\%20pesquisa\%20motores\%2007 /avaliacao\%20proconve.pdf

Li C, Taneda S, Suzuki AK, Furuta C, Watanabe G, Taya K. Estrogenic and anti-androgenic activities of 4-nitrophenol in diesel exhaust particles. Toxicol Appl Pharmacol, 2006;217 (1):1-6.

Lin CA, Pereira LA, Nishioka DC, Conceição GM, Braga AL, Saldiva PH. Air pollution and neonatal deaths in São Paulo, Brasil. Braz J Med Biol Res 2004;37:765-70.

Lichtenfels AJFC, Gomes JB, Pieri PC, El Khouri Miraglia SG, Hallak J, Saldiva PHN. Increased levels of air pollution and a decrease in the human and mouse male-to-female ratio in São Paulo, Brazil. Fertil Steril $2007 ; 87: 230-2$

Lubbert M, Oster W, Ludwig WD, Ganser A, Mertelsmann R, Herrmann F. A switch toward demethylation is associated with the expression of 
myeloperoxidase in acute myeloblastic and promyelocytic leukemias. Blood 1992; 80: 2066-73.

Luo ZC, Fraser WD, Julien P, Deal CL, Audibert F, Smith GN, Xiong X, Walker M. Tracing the origins of "fetal origins" of adult diseases: Programming by oxidative stress? Med Hypoth 2006; 66: 38-44.

Mahjub H, Sadri GH. Meta-analysis of case-referent studies of specific environmental or occupational pollutants on lung cancer. Indian J Cancer. 2006; 43(4):169-73.

Maheswaran R, Pearson T, Smeeton NC, Beevers SD, Campbell MJ, Wolfe CD. Impact of Outdoor Air Pollution on Survival After Stroke PopulationBased Cohort Study. Stroke, 2010;41:869-877.

Maluf M, Perin PM, Foltran Januário DA, Nascimento Saldiva PH. In vitro fertilization, embryo development, and cell lineage segregation after preand/or postnatal exposure of female mice to ambient fine particulate matter.Fertil Steril 2009; 92(5):1725-35.

Miao M, Yuan W, Zhu G, He X, Li DK. In utero exposure to bisphenol-A and its effect on birth weight of offspring. Reprod Toxicol. 2011 Mar 31. [Epub ahead of print]

Mohallem SV, de Araújo Lobo DJ, Pesquero CR, Assunção JV, de Andre PA, Saldiva PHN, Dolhnikoff M. Decreased fertility in mice exposed to environmental air pollution in the city of São Paulo. Environ Res 2005;98:196 -202.

Morley R. Fetal origins of adult disease. Semin Fetal Neonatal Med 2006; 11: 73-78. 
Nagy A, Gertsenstein M, Vintersten V, Behringer R. Surgical Procedures, In: Nagy A, Gertsenstein M, Vintersten V, Behringer R. Manipulating the Mouse Embryo: A Laboratory Manual, 2003, New York: Cold Spring Harbor Laboratory Press, pp,251-288.

Nawrot TS, Adcock I. The detrimental health effects of traffic-related air pollution: a role for DNA methylation? Am J Respir Crit Care Med 2009;179(7):523-4.

Odom LN, Taylor HS. Environmental induction of the fetal epigenome. Expert Rev Obstet Gynecol. 2010;5(6):657-664.

Ottinger MA. Mechanisms of reproductive aging: conserved mechanisms and environmental factors. Ann N Y Acad Sci, 2010; 1204:73-81.

Pereira LA, Loomis D, Conceição GM, Braga AL, Arcas RM, Kishi HS, Singer JM, Böhm GM, Saldiva PH. Association between air pollution and intrauterine mortality in São Paulo, Brasil. Environ Health Perspect 1998;106:325-9.

Perera F, Tang WY, Herbstman J, Tang D, Levin L, Miller R, Ho SM. Relation of DNA methylation of 5 '-CpG island of ACSL3 to transplacental exposure to airborne polycyclic aromatic hydrocarbons and childhood asthma. PLoS ONE. 2009;4:4488.

Pokholok DK, Harbison CT, Levine S, Cole M, Hannett NM, Lee TI, Bell GW, Walker K, Rolfe PA, Herbolsheimer E, Zeitlinger J, Lewitter F, Gifford DK, Young RA. Genome-wide map of nucleosome acetylation and methylation in yeast. Cell. 2005;122:517-527.

Pope CA III. Epidemiology of Fine Particulate Air Pollution and Human Health: Biologic Mechanisms and Who's at Risk? Environmental Health Perspectives 2000; 108(4): 713-23. 
Pope DP, Mishra V, Thompson L, Siddiqui AR, Rehfuess EA, Weber M, Bruce NG. Risk of low birth weight and stillbirth associated with indoor air pollution from solid fuel use in developing countries. Epidemiol Rev 2010; 32(1):70-81.

Povey AC, Stocks SJ. Epidemiology and trends in male subfertility. Hum Fertil (Camb) 2010 ;13(4):182-8.

Ramanathan V, Xu Y. The Copenhagen Accord for limiting global warming:

Criteria, constraints, and available avenues. PNAS 2010; 107 (18): 8055-62.

Skinner MK, Manikkam M, Guerrero-Bosagna C. Epigenetic transgenerational actions of environmental factors in disease etiology. Trends Endocrinol Metabol 2010;21(4):214-222.

Tam PPL, Snow MHL. Proliferation and migration of primordial germ cells during compensatory growth in mouse embryos. J Embryol Exp Morphol $1981 ; 64: 133-47$.

Tilly JL. Ovarian follicle counts--not as simple as 1, 2, 3. Reprod Biol Endocrinol 2003; 6: 1:11.

Turner BM. Histone acetylation as an epigenetic determinant of long-term transcriptional competence. Cell Mol Life Sci. 1998;54:21-31.

Tsukue N, Tsubone H, Suzuki AK. Diesel exhaust affects the abnormal delivery in pregnant mice and the growth of their young. Inhal Toxicol 2002; 14(6):635-51. 
Ulvestad B, Lund MB. Increased risk of chronic obstructive pulmonary disease among tunnel construction workers. Tidsskr Nor Laegeforen 2003; 28;123(16):2292-5.

Uzumcu M, Suzuki H, Skinner MK. Effect of the anti-androgenic endocrine disruptor vinclozolin on embryonic testis cord formation and postnatal testis development and function. Reprod Toxicol. 2004;18(6):765-74.

van Wagenen G, Simpson ME. Embryology of the ovary and testis; Homo sapiens and Macaca mulatta 1965. New Haven and London: Yale University Press.

Veras MM, Damaceno-Rodrigues NR, Silva RMG, Scoriza JN, Saldiva PHN, Caldini EG, Dolhnikoff M. Chronic exposure to fine particulate matter emitted by traffic affects reproductive and fetal outcomes in mice. Environmental Research 2009; 109: 536-543.

Veras MM, Damaceno-Rodrigues NR, Caldini EG, Ribeiro AACM, Mayhew TM, Saldiva PHN, Dolhnikoff M. Particulate Urban Air Pollution Affects the Functional Morphology of Mouse Placenta. Biology of Reproduction 2008;79: 578-584.

Watanabe N. Decreased number of sperms and Sertoli cells in mature rats exposed to diesel exhaust as fetuses. Toxicology Letters 2005; $155(1,15)$ : 51-58.

Watanabe N, Oonuki $\mathrm{Y}$. Inhalation of diesel engine exhaust affects spermatogenesis in growing male rats. Environ Health Perspect. 1999; 107(7):539-44. 
Weber LK, Keri RA. Bisphenol A Increases Mammary Cancer Risk in Two Distinct Mouse Models of Breast Cancer. Biol Reprod. 2011 [Epub ahead of print].

Witschi E. Migration of the germ cells of human embryos from the yolk sac to the primitive gonadal folds. Contrib Embryol 1948;209:67-80.

World Health Organization (WHO). Air Quality Guidelines, Global Update 2005. Available at: http://www,euro,who,int/Document/E90038,pdf, Accessed April 15, 2011.

Wu J, Ren C, Delfino RJ, Chung J, Wilhelm J, Ritz в. Association between Local Traffic-Generated Air Pollution and Preeclampsia and Preterm Delivery in the South Coast Air Basin of California. Environmental Health Perspectives 2009;117 (11) p 1773-9.

Yauk C, Polyzos A, Rowan-Carroll A, Somers CM, Godschalk RW, Van Schooten FJ, Berndt ML, Pogribny IP, Koturbash I, Williams A, et al. Germline mutations, DNA damage, and global hypermethylation in mice exposed to particulate air pollution in an urban/industrial location. Proc Natl Acad Sci U S A. 2008;105:605-610. 
Apêndice 


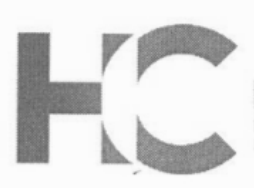

\section{APROVAÇĀO}

A Comissão de Ética para Análise de Projetos de Pesquisa - CAPPesq da Diretoria Clínica do Hospital das Clínicas e da Faculdade de Medicina da Universidade de São Paulo, em sessão de 03/10/2007, APROVOU o Protocolo de Pesquisa n 0806/07, intitulado: "OS EFEITOS DA POLUIÇÃO ATMOSFÉRICA NA RESERVA OVARIANA DE CAMUNDONGOS" apresentado pelo Departamento de PATOLOGIA.

Cabe ao pesquisador elaborar e apresentar à CAPPesq, os relatórios parciais e final sobre a pesquisa (Resolução do Conselho Nacional de Saúde n 196, de 10/10/1996, inciso IX.2, letra "c").

Pesquisador (a) Responsável: PAULO HILÁRIO NASCIMENTO SALDIVA

Pesquisador (a) Executante: KAROLYN SASSI OGLIARI

CAPPesq, 05 de Outubro de 2007

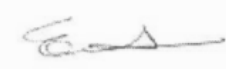

Prof. Dr. Eduardo Massad

Presidente da Comissão de Ética para Análise de

Projetos de Pesquisa

Comissão de Ética para Análise de Projetos de Pesquisa do HCFMUSP e da FMUSP Diretoria Clinica do Hospital das Clinicas da Faculdade de Medicina da Universidade de São Paulo Rua Ovidio Pires de Campos, 255, $5^{\circ}$ andar - CEP 05403010 - São Paulo - SP Fone: 01130696442 Fax: 01130696492 e-mail: cappesq@hcnet.usp.br / secretariacappesq2@hcnet.usp.br -sol 